\title{
Tributaries affect the thermal response of lakes to climate change
}

\author{
Love Råman Vinnå ${ }^{1}$, Alfred Wüest ${ }^{1,2}$, Massimiliano Zappa ${ }^{3}$, Gabriel Fink ${ }^{4}$, and Damien Bouffard ${ }^{1,2}$ \\ ${ }^{1}$ Physics of Aquatic Systems Laboratory - Margaretha Kamprad Chair, École Polytechnique Fédérale de Lausanne, \\ Institute of Environmental Engineering, Lausanne, Switzerland \\ ${ }^{2}$ Eawag, Swiss Federal Institute of Aquatic Science and Technology, Surface Waters - Research and Management, \\ Kastanienbaum, Switzerland \\ ${ }^{3}$ Swiss Federal Institute for Forest, Snow and Landscape Research, WSL, Birmensdorf, Switzerland \\ ${ }^{4}$ Center for Environmental Systems Research, CESR, University of Kassel, Kassel, Germany
}

Correspondence: Love Råman Vinnå (love.ramanvinna@epfl.ch)

Received: 14 June 2017 - Discussion started: 3 July 2017

Revised: 17 October 2017 - Accepted: 8 November 2017 - Published: 4 January 2018

\begin{abstract}
Thermal responses of inland waters to climate change varies on global and regional scales. The extent of warming is determined by system-specific characteristics such as fluvial input. Here we examine the impact of ongoing climate change on two alpine tributaries, the Aare River and the Rhône River, and their respective downstream peri-alpine lakes: Lake Biel and Lake Geneva. We propagate regional atmospheric temperature effects into river discharge projections. These, together with anthropogenic heat sources, are in turn incorporated into simple and efficient deterministic models that predict future water temperatures, river-borne suspended sediment concentration (SSC), lake stratification and river intrusion depth/volume in the lakes. Climate-induced shifts in river discharge regimes, including seasonal flow variations, act as positive and negative feedbacks in influencing river water temperature and SSC. Differences in temperature and heating regimes between rivers and lakes in turn result in large seasonal shifts in warming of downstream lakes. The extent of this repressive effect on warming is controlled by the lakes hydraulic residence time. Previous studies suggest that climate change will diminish deep-water oxygen renewal in lakes. We find that climaterelated seasonal variations in river temperatures and SSC shift deep penetrating river intrusions from summer towards winter. Thus potentially counteracting the otherwise negative effects associated with climate change on deep-water oxygen content. Our findings provide a template for evaluating the response of similar hydrologic systems to on-going climate change.
\end{abstract}

\section{Introduction}

The thermal and hydrodynamic responses of lakes to climate change are considerably diverse. Observed responses vary on global, regional and even local scales (O'Reilly et al., 2015). Even neighboring freshwater bodies can react differently to a given increase in air temperature. This indicates that lake-specific characteristics will determine the response to climate change (for clarity and brevity, we refer to anthropogenic climate change simply as "climate change" or "climate" from now on). Local factors which affect climate warming of lakes include, among others, morphology (Toffolon et al., 2014), irradiance absorption (Kirillin, 2010; Williamson et al., 2015), local weather conditions (Zhong et al., 2016), stratification (Piccolroaz et al., 2015), atmospheric brightening (Fink et al., 2014a) and ice cover (Austin and Colman, 2007).

Throughflows affect epilimnion and hypolimnion temperatures of lakes. Studies of climate impact typically do not address these sorts of subtleties in lake dynamics due to a lack of data or difficulties in predicting future temperature and discharge conditions (Fenocchi et al., 2017). Several studies of large lakes suggest that major tributaries play only a minor role in climate-induced warming and deep-water oxygen renewal (Fink et al., 2014a; Schwefel et al., 2016). Mediumand smaller-scale lakes are, however, more abundant than large lakes (Verpoorter et al., 2014) and exhibit a greater degree of sensitivity to point sources of anthropogenic thermal input which can affect temperature and stratification (Kirillin et al., 2013; Råman Vinnå et al., 2017). Medium- and 
small-sized lakes also make a more significant contribution to the temperature-dependent global greenhouse gas budget (Holgerson and Raymond, 2016). Accurate prediction of climate change impacts therefore requires a more detailed understanding of small- to medium-scale lake and tributary systems.

Climate change exerts a dual influence on alpine rivers by introducing variation to both flow and temperatures. Discharge variation takes the form of less flow in summer and more flow in winter due to warmer high-altitude snow and ice melt/runoff regimes (Addor et al., 2014; Birsan et al., 2005), which also influence river temperature (Isaak et al., 2012; Van Vliet et al., 2013). Increased air temperature may also enhance erosion rates in river basins thereby supplementing river-borne suspended sediment loads (Bennett et al., 2013). River temperature and suspended sediment content determine water density and, by extension, the depth of river plume intrusions into downstream lakes or reservoirs. The depths and volumes of river intrusion plumes determine deep-water oxygen renewal, especially for deeper lakes where climate-related warming can reduce seasonal deep convective mixing and thereby deplete deep-water oxygen (Schwefel et al., 2016). Major (deep penetrating) river intrusion events typically occur due to flooding, which flush large sediment loads into the river (Fink et al., 2016). The frequency and volume of floods in the Alps are notoriously hard to predict, although a decrease in floods has occurred in association with recent warmer summers observed in the Alps (CH2011, 2011; Glur et al., 2013).

Recent model studies have identified inland waters as risk hotspots under expected climate change scenarios (IPCC, 2014). These systems require a more detailed analysis given their role in supporting fisheries, agriculture, drinking water supply, heat management and hydropower. This paper examines the complex interactions between tributaries and lakes in response to temperature increase and other modifications expected from climate change. Our objectives were to quantify the impact of specific climate change scenarios on (i) alpine tributaries and (ii) downstream peri-alpine lakes with a focus on river-borne suspended sediment concentration (SSC), water temperature, stratification and river intrusions.

We used coupled river-lake models to build on previous research by Fink et al. (2016). These authors investigated the effect of flood frequencies on deep-water renewal under established climate change scenarios. Their work did not generate tightly constrained estimates for flooding events. Our analysis therefore provisionally assumed that flood frequency does not change in the future. In addition to these sources of natural variation, our models addressed variation in river discharge regimes (i.e., daily mean level shift) under the specified A1B climate change scenario. These in turn affect SSC and thermal regimes for rivers and their associated downstream lakes. Furthermore, here we show that local point sources of anthropogenic thermal pollution can have

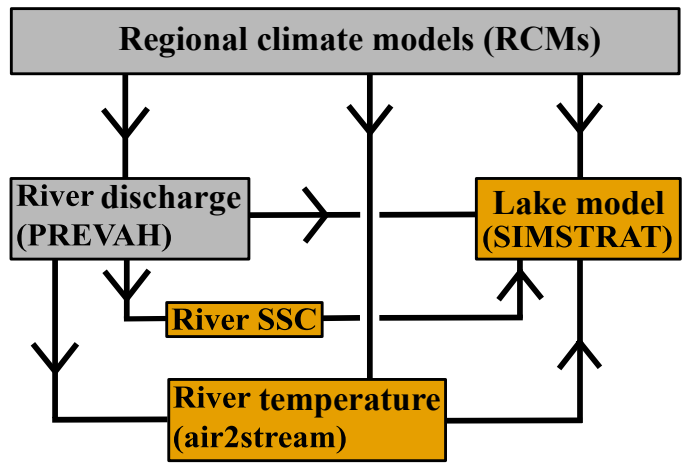

Figure 1. Schematic illustration of the one-way model chain of this study. Orange models represent modeling performed by this study, while grey models represent simulated data inputs obtained from external sources.

a major impact on the response of inland waters to climate change as previously suggested by Fink et al. (2014b).

\section{Methods}

\subsection{Approach}

The investigation of tributary influence on lake response to climate change followed these procedural steps:

i. Define river temperature and SSC models for two major alpine rivers and designate a one-dimensional lake model for a large- and medium-sized peri-alpine lake.

ii. Integrate model (i) with a river intrusion scheme: Fig. 1 shows the integration of the one-way component models.

iii. Obtain and apply estimates of future regional air temperature, tributary discharge and changes in local anthropogenic thermal emissions to both river and lake models.

iv. Identify patterns in model outputs of water temperature, SSC, lake stratification and river intrusion parameters (volume and depth).

\subsection{Study area}

This study examined two warm, monomictic, freshwater peri-alpine lakes in western Switzerland: Lake Biel (LB; $47^{\circ} 5^{\prime} \mathrm{N}, 7^{\circ} 10^{\prime} \mathrm{E}$ ) and Lake Geneva (LG; $46^{\circ} 27^{\prime} \mathrm{N}, 6^{\circ} 31^{\prime} \mathrm{E}$ ). Large tributaries originating in the Alps, the Aare River and the Rhône River, feed into LB and LG, respectively (Fig. 2).

LG is a large meso-eutrophic lake resting at $372 \mathrm{~m}$ elevation and covering an area of $580 \mathrm{~km}^{2}$. It reaches a maximum depth of $309 \mathrm{~m}$ and holds a volume of $89 \mathrm{~km}^{3}$ with an average hydraulic residence time of 11.5 years. Complete seasonal deep convective mixing only occurs on average every 


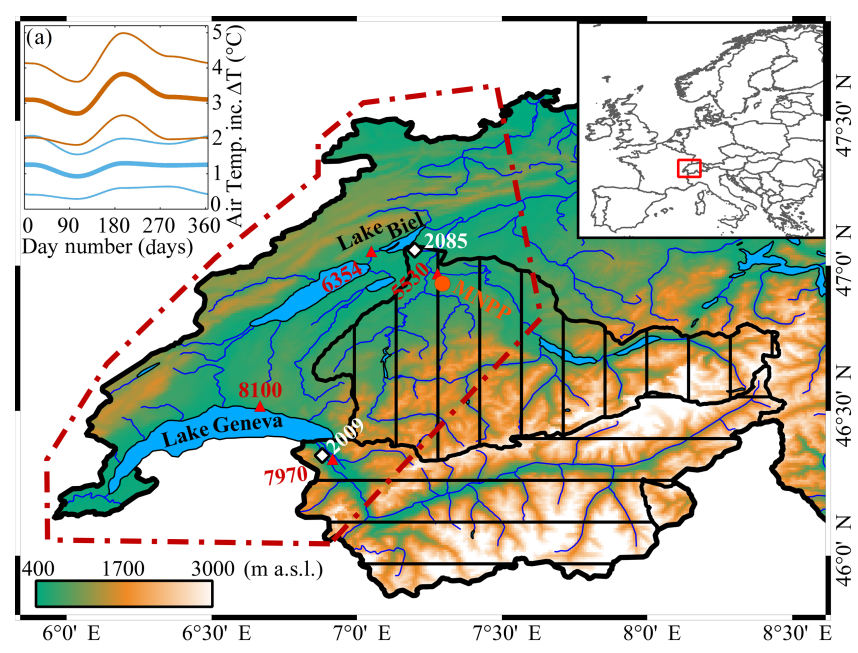

Figure 2. Study area and predicted regional air temperature increases. Elevation above sea level (green to white color ramp), locations and number of river stations (white diamonds) and atmospheric monitoring stations (red triangles), drainage area (Aare: vertical lines; Rhône: horizontal lines) and location of Mühleberg Nuclear Power Plant (MNPP, orange circle). Area covered by regional climate models (dark red dashed-dotted line) with (a) predicted air temperature increase $\Delta T$ in the near-future (blue, 2030-2049) and far-future (orange, 2080-2099) for medium (thick lines) and upper/lower estimates (thin lines) under the A1B emission scenario (CH2011, 2011).

fifth winter but is predicted to become less frequent with ongoing climate change (Perroud and Goyette, 2010; Schwefel et al., 2016). Whereas the global average lake surface temperature has increased by $\sim 0.34^{\circ} \mathrm{C}$ decade $^{-1}$ between 1985 and 2009 (O'Reilly et al., 2015), the Rhône River supplying $\sim 75 \%$ of LG's inflow has experienced a temperature increase of $\sim 0.21^{\circ} \mathrm{C}$ decade $^{-1}$ from 1978 to 2002 (Hari et al., 2006).

LB is a $74 \mathrm{~m}$ deep, meso-eutrophic, medium-sized lake resting at an elevation of $429 \mathrm{~m}$. It covers a surface area of $39.3 \mathrm{~km}^{2}$ and holds a volume of $1.18 \mathrm{~km}^{3}$ with a hydraulic residence time of 58 days. Complete deep convective mixing occurs every winter and effectively replenishes the oxygen-depleted deep-water. The Aare River provides $\sim 61 \%$ of LB's inflow and experienced a $0.34{ }^{\circ} \mathrm{C}$ decade $^{-1}$ increase in temperature from 1978 to 2002 (Hari et al., 2006). Several dams/lakes trap sediment along the upstream Aare course and increase sediment settling and water temperature prior to entering LB. The Mühleberg Nuclear Power Plant (MNPP), situated $\sim 19 \mathrm{~km}$ upstream from LB $\left(46^{\circ} 59^{\prime} \mathrm{N}\right.$, $7^{\circ} 16^{\prime} \mathrm{E}$; Fig. 2) represents a point-source of thermal pollution. Planned for decommission in 2019, the plant emits $\sim 700 \mathrm{MW}$ of heat into the Aare and substantially warms the river water (Råman Vinnå et al., 2017). The $\sim 8 \mathrm{~km}$ long Zihlkanal, LB's second largest tributary, supplies $\sim 32 \%$ of the lake inflow and connects LB to Lake Neuchâtel (Fig. 2). This tributary is neglected here since it mainly transports lake surface water, which has approximately the same temperature as LB surface water and thus without net heat effects.

\subsection{River models}

\subsubsection{Temperature}

Uncertainties concerning river morphology, heat fluxes, shadowing and atmospheric conditions such as wind speed and cloudiness (Caissie, 2006) pose a significant challenge to accurately model future river temperatures. Deterministic models typically require detailed knowledge unavailable for future climate scenarios. Regressions and stochastic models rely heavily on observed natural variability in a given time frame and typically do not include inputs representing additional or interacting physical processes. On their own, these sorts of "black box" models cannot balance trade-offs between constraints available from empirical data and the complexity offered by theoretical frameworks.

To overcome these limitations, we used the hybrid model air2stream (Toffolon and Piccolroaz, 2015). The model combines the simplicity of stochastic models with accurate representation of the relevant physical processes affecting temperature. Similar to the neural networks approach, the model calculates river water temperature $\left(T_{\mathrm{w}}\right)$ through a MonteCarlo-like calibration process, which identifies optimal parameters for weighting physically dependent variables. We used the eight-parameter $\left(a_{1}\right.$ to $\left.a_{8}\right)$ version of the model which incorporates air temperature $\left(T_{\mathrm{a}}\right)$ and river discharge $(Q)$ as a function of time $(t)$.

$$
\begin{aligned}
\frac{\Delta T_{\mathrm{w}}}{\Delta t}= & \frac{1}{\delta}\left\{a_{1}+a_{2} T_{\mathrm{a}}(t)-a_{3} T_{\mathrm{w}}(t)\right. \\
& \left.+\theta\left[a_{5}+a_{6} \cos \left(2 \pi\left(\frac{t}{t_{y}}-a_{7}\right)\right)-a_{8} T_{\mathrm{w}}(t)\right]\right\}, \\
\delta= & \theta^{a_{4}}, \quad \theta=Q(t) / \bar{Q}
\end{aligned}
$$

where $t$ is expressed in years and $t_{y}$ represents 1 year. Both the Aare and Rhône (stations nos. 2085 and 2009, respectively; Fig. 2) provided calibration (1990-1999) and validation data (2000-2009). Table 1 and Fig. 3 show best-fit parameters and model performance statistics. Model sensitivity to variation in $T_{\mathrm{w}}$ was assessed by removing MNPP thermal pollution as in Råman Vinnå et al. (2017) and repeating the calibration/validation for station no. 2085 (Table 1).

\subsubsection{Suspended sediment concentration}

Water density and intrusion depth of river water into downstream lakes is influenced by SSC. Intensive flow events create high levels of SSCs (Rimmer and Hartmann, 2014), as can exposure/erosion of sediment sources within the river basin through the so-called hysteresis effect, in which SSC varies for the same level of discharge (Tananaev, 2012). River 
Table 1. air2stream river temperature model best-fit parameters and model performance statistics reported as coefficients of determination $\left(R^{2}\right)$ and root mean square deviation (RMSD). Input parameters used in this study are shown in bold-faced type. The model was calibrated, validated and subjected to sensitivity tests using data from station no. 2085 (Aare River) representing past observed conditions and future predicted conditions assuming MNPP removal (No MNPP).

\begin{tabular}{|c|c|c|c|}
\hline \multirow{2}{*}{$\begin{array}{l}\text { Parameter } \\
\text { (unit) }\end{array}$} & \multicolumn{2}{|c|}{ Aare (no. 2085) } & \multirow{2}{*}{$\begin{array}{r}\text { Rhône (no. 2009) } \\
\text { Measurements }\end{array}$} \\
\hline & Measurements & No MNPP & \\
\hline $\mathrm{a}_{1}\left({ }^{\circ} \mathrm{C} \mathrm{day}^{-1}\right)$ & 2.0316 & 0.6434 & 1.4927 \\
\hline $\mathrm{a}_{2}\left(\mathrm{day}^{-1}\right)$ & 0.2299 & 0.3855 & 0.2774 \\
\hline $\mathrm{a}_{3}\left(\right.$ day $\left.^{-1}\right)$ & 0.2267 & 0.3177 & 0.4133 \\
\hline $\mathrm{a}_{4}(-)$ & 0.0157 & 0.5622 & 0.6399 \\
\hline $\mathrm{a}_{5}\left({ }^{\circ} \mathrm{C} \mathrm{day}^{-1}\right)$ & 6.7022 & 16.2387 & 6.4792 \\
\hline $\mathrm{a}_{6}\left({ }^{\circ} \mathrm{C} \mathrm{day}^{-1}\right)$ & 4.4950 & 9.9855 & 2.3224 \\
\hline $\mathrm{a}_{7}(-)$ & 0.6066 & 0.6066 & 0.5244 \\
\hline \multirow[t]{2}{*}{$\mathrm{a}_{8}\left(\mathrm{day}^{-1}\right)$} & 0.7156 & 1.5930 & 1.0760 \\
\hline & \multicolumn{3}{|c|}{$R^{2}(-)$} \\
\hline Calibration $^{\mathrm{a}}$ & 0.97 & 0.96 & 0.94 \\
\hline \multirow[t]{2}{*}{ Validation $^{\mathrm{b}}$} & 0.95 & 0.96 & 0.94 \\
\hline & \multicolumn{3}{|c|}{$\operatorname{RMSD}\left({ }^{\circ} \mathrm{C}\right)$} \\
\hline Calibration $^{\mathrm{a}}$ & 0.83 & 0.95 & 0.52 \\
\hline Validation $^{\mathrm{b}}$ & 1.02 & 1.06 & 0.59 \\
\hline
\end{tabular}

a 1990-1999; b 2000-2009

discharge regimes have been predicted to change in the future (Birsan et al., 2005), suggesting that SSCs will also change. To simulate future SSCs, we used the supply-based rating model described in Doomen et al. (2008), which Fink et al. (2016) adapted to the River Rhine.

The model consists of a base level SSC $\left(\mathrm{g} \mathrm{m}^{-3}\right)$ function expanded to express erosion of sediment at high discharge and sediment accumulation at low discharge. The model is expressed as

$\operatorname{SSC}(t)=$

$m+b_{1} Q(t)^{c_{1}}+d_{1} d_{2} b_{2}\left(Q(t)-Q_{\mathrm{th}}\right)^{c_{2}}-b_{3}\left(1-d_{2}\right)$,

where $b_{x}, c_{x}$ and $m$ are adjustable parameters in combination with the threshold discharge $\left(Q_{\text {th }}\right)$, which determines whether erosion or deposition occurs within the river. The parameters $d_{1}$ and $d_{2}$ control the deposition of (or erosion from) the river sediment storage $(\psi(\mathrm{g}))$.

$d_{1}=\left\{\begin{array}{c}0: \psi=0 \\ 1: \psi>0\end{array}\right.$,

$d_{2}=\left\{\begin{array}{l}0: Q \leq Q_{\mathrm{th}} \\ 1: Q>Q_{\mathrm{th}}\end{array}\right.$

Erosion occurs if $Q$ exceeds $Q_{\text {th }}$ and the river basin contains erodible sediment $(\psi>0)$. Sedimentation occurs if $Q$
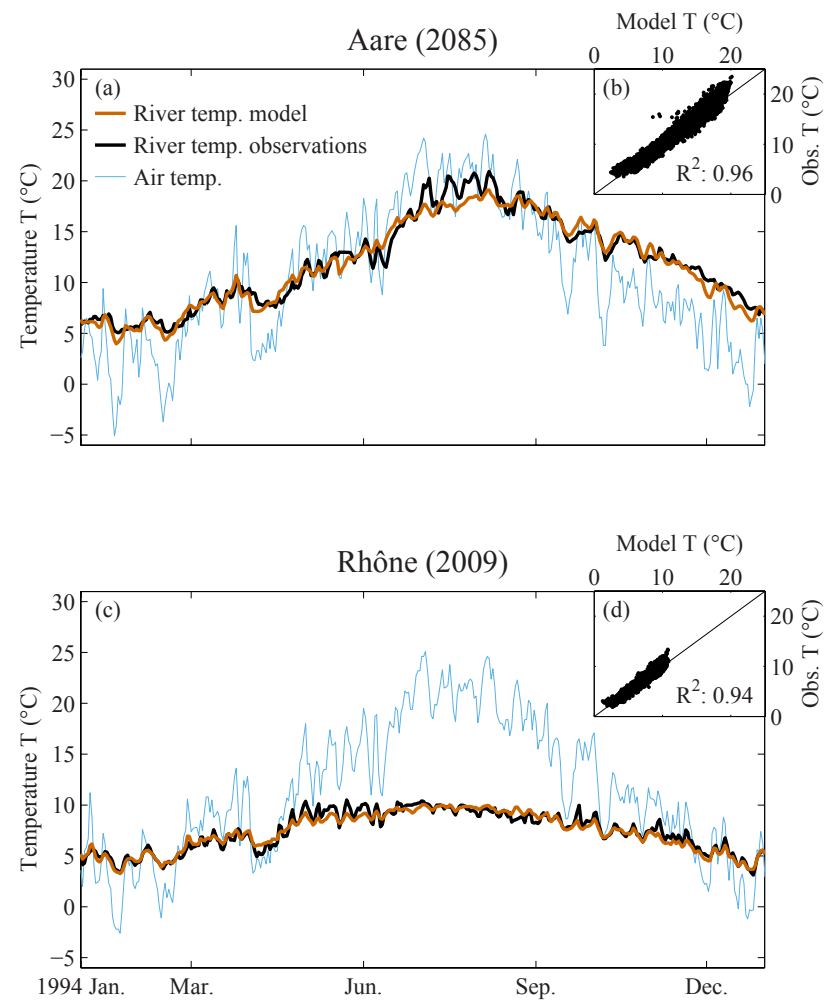

Figure 3. air2stream modeled (orange) and measured (black) temperature ( $T$ ) compared to air temperature (blue) for (a) Aare River and (c) Rhône River in 1994. The insets (b) and (d) show modeled versus observed temperature from 1990 to 2009 with coefficient of determination $\left(R^{2}\right)$.

is smaller than $Q_{\text {th. }}$. The change in $\psi$ over time can be formulated as

$\frac{\Delta \psi}{\Delta t}=\left(b_{3}\left(1-d_{2}\right)-d_{1} d_{2} b_{2}\left(Q(t)-Q_{\mathrm{th}}\right)^{c_{2}}\right) Q(t)$.

Parameters in Eqs. (3) to (6) were calibrated (2013) and validated (2014) through an evolutionary algorithm (Fink et al., 2016). Table 2 and Fig. 4 give model performance statistics and best-fit parameter values.

\subsection{Lake model}

We used the one-dimensional model SIMSTRAT (Goudsmit et al., 2002) to assess the impact of climate change on temperature and deep-water renewal in LB and LG. The model calculates heat fluxes and vertical mixing driven by wind and the internal wave field using a $k-\varepsilon$ turbulence closure scheme. It has been adapted to and validated for multiple lakes including Lake Zürich (Peeters et al., 2002), LG (Perroud and Goyette, 2010; Schwefel et al., 2016), Lake Neuchâtel (Gaudard et al., 2017), Lake Constance (Fink et al., 2014b; Wahl and Peeters, 2014) and LB (Råman Vinnå et al., 2017). 
Table 2. River suspended sediment concentration (SSC) model best-fit parameters and model performance statistics reported as coefficients of determination $\left(R^{2}\right)$ and root mean square deviation (RMSD).

\begin{tabular}{lrr}
\hline Parameter (unit) & Aare (no. 2085) & Rhône (no. 2009) \\
\hline$m\left(\mathrm{~g} \mathrm{~m}^{-3}\right)$ & 8.8000 & 1.0000 \\
$\mathrm{~b}_{1}\left(\mathrm{~g} \mathrm{day} \mathrm{m}^{-6}\right)$ & 0.2650 & 0.0006 \\
$\mathrm{c}_{1}(-)$ & 0.6500 & 2.3200 \\
$\mathrm{~b}_{2}\left(\mathrm{~g} \mathrm{day} \mathrm{m}^{-6}\right)$ & 0.0011 & 0.0010 \\
$\mathrm{c}_{2}(-)$ & 2.3000 & 12.0000 \\
$\mathrm{~b}_{3}\left(\mathrm{~g} \mathrm{~m}^{-3}\right)$ & 8.8000 & 2.0000 \\
$Q_{\text {th }\left(\mathrm{m}^{3} \text { day }^{-1}\right)}$ & 401 & 232 \\
\hline & $R^{2}(-)$ & 0.74 \\
\hline Calibration $^{\mathrm{a}}$ & 0.20 & 0.58 \\
Validation $^{\mathrm{b}}$ & 0.03 & 206 \\
\hline & $\mathrm{RMSD}\left(\mathrm{g} \mathrm{m}^{-3}\right)$ & 222 \\
\hline Calibration $^{\mathrm{a}}$ & 82 & \\
Validation $^{\mathrm{b}}$ & 217 & \\
\hline a 2013; b 2014
\end{tabular}
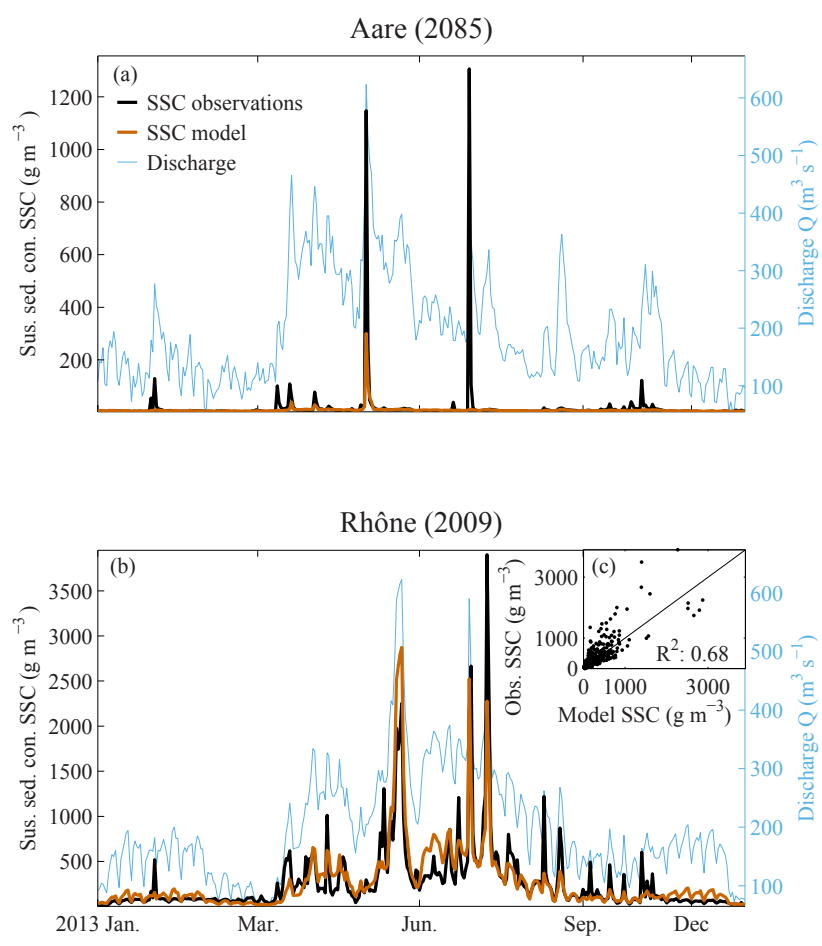

Figure 4. Modeled (orange) and measured (black) suspended sediment concentration (SSC) compared to river discharge Q (blue) for (a) Aare River and (b) Rhône River in 2013. The insert (c) shows modeled versus observed SSC for 2013 and 2014 in the Rhône River with coefficient of determination $\left(R^{2}\right)$.
Table 3. One-dimensional lake model SIMSTRAT best-fit parameters and model performance statistics reported as vertical volumeweighted averaged root mean square deviation (RMSD-V).

\begin{tabular}{|c|c|c|}
\hline Parameter (unit) & Lake Biel & Lake Geneva \\
\hline$p_{1}(-)$ & 1.30 & 1.09 \\
\hline$p_{2}(-)$ & 1.20 & 0.90 \\
\hline$K(-)$ & 0.70 & 1.40 \\
\hline$q(-)$ & 1.30 & 1.25 \\
\hline$C_{\text {Deff }}(-)$ & 0.0050 & 0.0020 \\
\hline$C_{10}(-)$ & 0.0016 & 0.0017 \\
\hline$a_{\mathrm{S}}(-)$ & 0.0060 & 0.035 \\
\hline$a_{\mathrm{W}}(-)$ & 0.0040 & 0.009 \\
\hline \multicolumn{3}{|c|}{ RMSD-V $\left({ }^{\circ} \mathrm{C}\right)$} \\
\hline Calibration & $0.73^{\mathrm{a}}$ & $0.66^{\mathrm{c}}$ \\
\hline Validation & $0.68^{\mathrm{b}}$ & \\
\hline
\end{tabular}

a $1995-2004$; $^{2} 2005-2015$; $^{1} 1981-2012$.

The model contains seven tunable parameters, including $p_{1}$ (irradiance absorption), $p_{2}$ (sensible heat flux) and $K$ (vertical light absorption) for heat flux adjustments from the atmosphere to the lake. Momentum and kinetic energy transfer from the wind to internal waves is tunable by $C_{10}$ (wind drag). The internal seiche energy balance can be adjusted through $\alpha$ (production), $C_{\text {Deff }}$ (loss by bottom friction) and $q$ (vertical distribution of turbulent kinetic energy). To include the effect of seasonally varying stratification strength, we followed Schwefel et al. (2016) and varied $\alpha: \alpha_{\mathrm{S}}$ for summer (April to September) and $\alpha_{\mathrm{W}}$ for winter (October to March), where $\alpha_{\mathrm{S}}>\alpha_{\mathrm{W}}$. Here we used the best-fit parameter setup (Table 3) already established and validated for LG and LB by Schwefel et al. (2016) and Råman Vinnå et al. (2017).

Building upon the model developed by Råman Vinnå et al. (2017), we introduced an extended river intrusion scheme described in Appendix A1 (including sensitivity analysis). This scheme was chosen in order to include the effect of steep bathymetry on plume entrainment. Additionally, the robustness and simplicity of the intrusion scheme limits the uncertainty associated with more complex intrusion models including multiple parameters which can be hard to predict in the future. The entrainment of lake water into plunging underflows was modeled as proposed by Akiyama and Heinz (1984) with additional sedimentation of suspended load (Mulder et al., 1998; Syvitski and Lewis, 1992). The method addresses the transition of a homogenous open channel flow to a stratified underflow where entrainment and settling of sediment depend on bottom slope angle. The model scheme consists of (i) the homogenous region, where river water extends from the surface to the lake bed; (ii) the plunging region, where the plume separates from the lake surface and (iii) the underflow region, where the plume descends downslope while entraining surrounding water until it sepa- 
rates from the bottom and intrudes into the lake interior (Fink et al., 2016).

\subsection{Data, hydrology and climate forcing}

The models described above used hourly resolved data from 1989 to 2009 as inputs. For calibration/validation of river temperature, we used flow and temperature data from the Aare monitoring station no. 2085 (Fig. $2 ; 47^{\circ} 03^{\prime} \mathrm{N}, 7^{\circ} 11^{\prime} \mathrm{E}$ ) and from the Rhône monitoring station no. 2009 (Fig. 2; $\left.46^{\circ} 21^{\prime} \mathrm{N}, 6^{\circ} 53^{\prime} \mathrm{E}\right)$. The nearest meteorological stations, Mühleberg (no. 5530 in Fig. 2; $46^{\circ} 58^{\prime} \mathrm{N}, 7^{\circ} 17^{\prime} \mathrm{E}$ ) for Aare and Aigle (no. 7970 in Fig. 2; $46^{\circ} 20^{\prime} \mathrm{N}, 6^{\circ} 55^{\prime} \mathrm{E}$ ) for Rhône, provided air temperature data. Due to insufficient representation of high turbidity events, we calibrated/validated the SSC model with turbidity data converted to SSC with suspended sediment samples from 2013 and 2014.

The meteorological data used for SIMSTRAT included air temperature, vapor pressure, wind speed, solar radiation and cloud cover. These data were collected from the meteorological stations Cressier (no. 6354 in Fig. $2 ; 47^{\circ} 03^{\prime} \mathrm{N}$, $7^{\circ} 03^{\prime} \mathrm{E}$ ) for $\mathrm{LB}$ and Pully (no. 8100 in Fig. 2; 46 $31^{\prime} \mathrm{N}$, $\left.6^{\circ} 40^{\prime} \mathrm{E}\right)$ for LG. Råman Vinnå et al. (2017) and Schwefel et al. (2016) provide additional information on climate data inputs to the one-dimensional model. The river intrusion scheme requires as input the slope angle traveled by the river underflow, which was obtained from a $25 \mathrm{~m}$ resolved digital height model (DHM25). Vertical temperature profiles, sampled at the deepest location of both lakes in January 1989, were used as initial conditions.

Van Vliet et al. (2013) suggested that river discharge and air temperature should be used while predicting future river temperatures. We incorporated recent findings of climateinduced changes in air temperature and river discharge regimes to model both future river temperature and SSC. Seasonal mean predictions for air temperature increase in western Switzerland (Fig. 2) were estimated from CH2011 (2011) for the A1B emission scenario (balanced use of renewable and fossil fuels) using results from 20 regional climate models. Flow projections were obtained from published results generated by the PREVAH (PREcipitation-RunoffEVApotranspiration HRU Model) hydrological model (Viviroli et al., 2009) using a gridded configuration as described in Speich et al. (2015) and Kobierska et al. (2011). The model explicitly incorporates changes in glacial extent, snow melt, catchment runoff, floods and low water flows (FOEN, 2012; Bosshard et al., 2013; Speich et al., 2015). The PREVAH outcomes for the 1981-2009 period have been validated with data from 65 river gauges (Speich et al., 2015), including the two gauges upstream of LG (Rhône; no. 2009 in Fig. 2) and LB (Aare; no. 2085 in Fig. 2) used here.

Hydrol. Earth Syst. Sci., 22, 31-51, 2018

\subsection{Scenarios}

Six different model scenarios were used to propagate climate change effects through the major tributaries and their associated downstream lakes. Model scenarios LG1 to LG3 represented LG while LB1 to LB3 represented LB (Table 4). Each scenario includes three time periods: a reference period (1990-2009), a near-future period (2030-2049) and a far-future period (2080-2099). The 20-year intervals allowed us to resolve natural variations on seasonal and shorter time scales. We initialized the models 1 year prior to the investigated period for each time frame (1989, 2029 and 2079) in order to remove effects of initial conditions.

Scenarios LG1 and LB1 excluded river inflow in order to isolate lake response to climate change from potential tributary influence. Scenarios LG2, LG3, LB2 and LB3 were used to differentiate between the effects of tributary temperature and SSC, and to provide model sensitivity estimates. The LB3 scenario excluded MNPP thermal pollution from near-future and far-future time periods but not from the reference period. The LB2 scenario included thermal pollution in modeling river water temperature. Scenarios LB2, LB3 and LG3 included SSC while LG2 did not. Low SSC values found in the Aare data resulted in negligible differences between models including and excluding SSC. Because they served primarily validation and sensitivity analysis purposes, the Aare/LB model results excluding particles and including/excluding MNPP thermal pollution (LB4 and LB5) are relegated to Appendix Fig. B1 and not discussed further. Scenarios LG3 and LB3 represent expected future developments.

The unmodified air temperature and modeled river discharge, temperature and SSC were used as inputs for the reference periods. Near-future and far-future models incorporated predicted changes in air temperature and river discharge, temperature and SSC with maximum, medium or mean, and minimum values serving as envelopes for each parameter (Figs. 2a and 5). This strategy gave nine simulations (three for scenarios LG1 and LB1, which exclude rivers; i.e., no variation in discharge nor river temperature) for each nearfuture and far-future time period. Predicted results included a total of 87 model runs. Upper, mean and lower impact estimates (described and interpreted below) were derived from the nine basic model runs.

\section{Results}

\subsection{Rivers}

The seasonality of predicted river discharge $(Q)$ from FOEN (2012) varies with respect to the reference period 1990-2009 (Fig. 5a and b). The PREVAH model shows a future decrease in mean summer discharge (1 April to 30 September) for both the Aare $\left(-3.7 \mathrm{~m}^{3} \mathrm{~s}^{-1}\right.$ decade $^{-1}$; no. 2085) and Rhône 
Table 4. Model scenarios of climate change effects for near-future and far-future time periods, including (Inc.) and excluding (Exc.) the effects of rivers and suspended sediment. Thermal input from MNPP was also included/excluded. Most likely scenarios are shown in bold.

\begin{tabular}{lcc|c}
\hline Lake & Exc. rivers & \multicolumn{2}{c}{ Inc. rivers } \\
\cline { 3 - 4 } & & Exc. suspended sediment & Inc. suspended sediment \\
Geneva & LG1 & LG2 & LG3 \\
Biel & LB1 & Inc. MNPP & Exc. MNPP \\
\hline
\end{tabular}

$\left(-3.8 \mathrm{~m}^{3} \mathrm{~s}^{-1}\right.$ decade $^{-1}$; no. 2009). The decrease in summer will be compensated by an observed increase in winter flow (1 October to $31 \mathrm{March}$ ) of the Aare $\left(+3.3 \mathrm{~m}^{3} \mathrm{~s}^{-1}\right.$ decade $\left.^{-1}\right)$ and Rhône $\left(+3.7 \mathrm{~m}^{3} \mathrm{~s}^{-1}\right.$ decade $\left.^{-1}\right)$. These results confirm previous findings presented by Addor et al. (2014) and Bosshard et al. (2013).

Regional air temperatures from the A1B emission scenario $\left(\sim+0.32^{\circ} \mathrm{C}\right.$ decade $^{-1}$; CH2011, 2011; Fig. 2a) cause a predicted increase in mean annual water temperature $(T)$ for both the Aare $\left(\sim+0.10^{\circ} \mathrm{C}\right.$ decade $\left.^{-1}\right)$ and the Rhône $\left(\sim+0.08^{\circ} \mathrm{Cdecade}^{-1}\right)$. Both rivers experience seasonal variations in temperature increase similar to that predicted for air temperatures (Figs. 2a, 5e and f). The effect is strongest for the Aare during summer with warming of up to $+2.5^{\circ} \mathrm{C}$ in water temperatures for the far-future time period relative to the reference period.

Thermal pollution from the MNPP in the Aare during the reference period (blue-green line in Fig. 5e; Råman Vinnå et al., 2017) causes approximately twice as much heating in winter relative to warming from climate change in the far-future. In summer, the relationship reverses with minor MNPP warming relative to that induced by climate change. The net effect of climate warming and MNPP decommission (i.e., removal of MNPP heat from near-future and far-future time periods) on the Aare is cooling in winter and warming in summer relative to the reference period (Fig. 5c).

Like river temperatures, SSCs depend on river discharge. Our model therefore show SSC increasing in winter and decreasing in summer due to shifts in the discharge regime (Fig. 5g and h). The model results for the Rhône exhibit a mean seasonal increase of $+14 \mathrm{~g} \mathrm{~m}^{-3} \mathrm{decade}^{-1}$ in winter and a decrease of $-11 \mathrm{~g} \mathrm{~m}^{-3}$ decade $^{-1}$ in summer. For reasons explained above (Sect. 2.2), results for the Aare show less variation, with a seasonal increase of $+0.3 \mathrm{~g} \mathrm{~m}^{-3} \mathrm{decade}^{-1}$ in winter and a decrease of $-0.4 \mathrm{~g} \mathrm{~m}^{-3}$ decade $^{-1}$ in summer. Altered temperature and SSC caused increases and decreases in water density for both rivers in winter and summer, respectively.

\subsection{Lakes}

Warmer air temperatures (Fig. 2a) predicted from climate change resulted in temperature increases in both LG and LB for all scenarios (Table 5). Models showed the highest warming rates in the epilimnion, intermediate values throughout
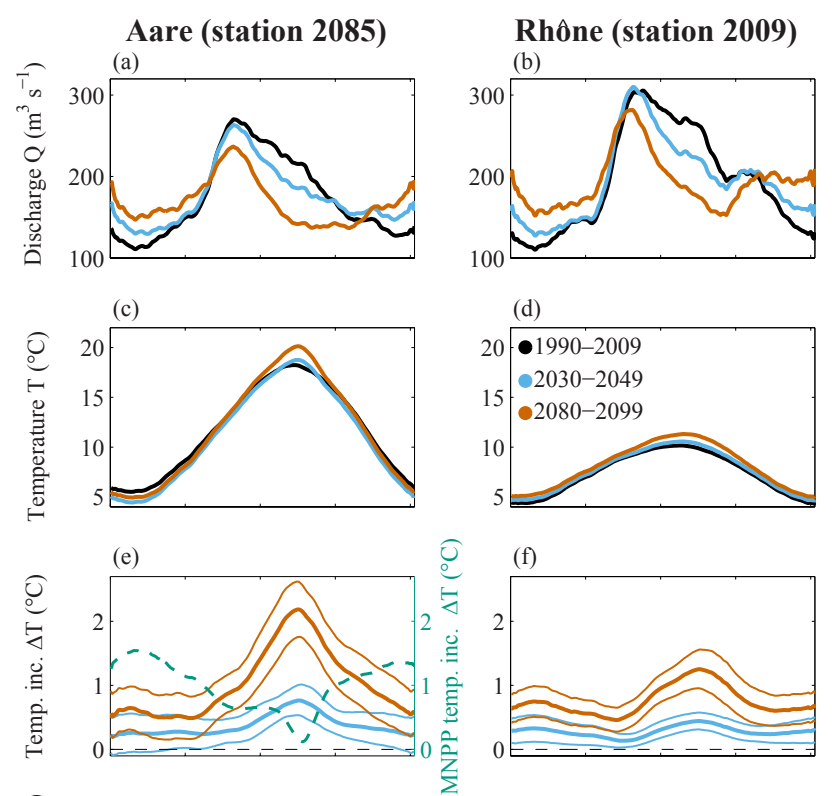

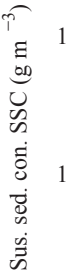
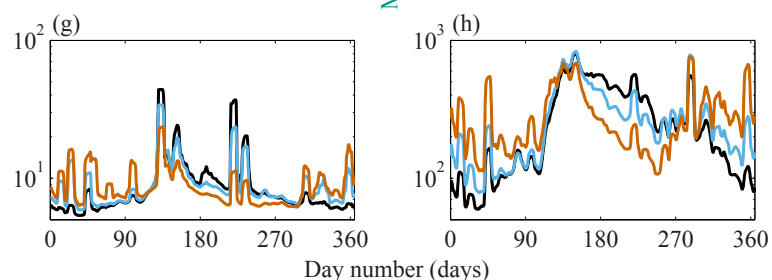

Figure 5. Modeled climate impact from scenarios LB3 (Aare River; $\mathbf{a}, \mathbf{c}, \mathbf{e}, \mathbf{g}$ ) and LG3 (Rhône River; b, d, f, h) displayed as daily average for reference (black, 1990-2009), near-future (blue, 20302049) and far-future (orange, 2080-2099) time periods. Discharge $Q$ (a and b), net water temperature $T$ (c and d) with anthropogenic heat from Mühleberg Nuclear Power Plant (MNPP) removed from near-future and far-future time periods, temperature increase $\Delta T$ (e and $\mathbf{f}$ ) due to climate change (orange/blue), MNPP (blue-green) and modeled SSC ( $\mathbf{g}$ and $\mathbf{h}$ ). Maximum and minimum modeled values are marked by fine lines (e and $\mathbf{f}$ ) and/or are omitted $(\mathbf{c}, \mathbf{d}, \mathbf{g}$, and $\mathbf{h}$ ) for clarity.

the metalimnion and the lowest rates in the hypolimnion (Table 5). We defined the epilimnion, metalimnion and hypolimnion using the water column stability method described in Råman Vinnå et al. (2017). The predicted warming of LG varied only slightly among the three different scenarios 
Table 5. Change in temperature, length of the stratified period and depth of the thermocline (negative values correspond to a shallower thermocline) for each scenario listed in Table 4. Estimates given as mean of the daily difference between the reference period and the far-future time period. Temperature anomalies are volume-weighted and vertically averaged. Most likely scenarios are shown in bold.

\begin{tabular}{|c|c|c|c|c|c|}
\hline \multirow[t]{2}{*}{ Scenario } & \multicolumn{3}{|c|}{$\begin{array}{l}\text { Temperature } \\
\left({ }^{\circ} \mathrm{C} \text { decade }^{-1}\right)\end{array}$} & \multirow[t]{2}{*}{$\begin{array}{r}\text { Stratification } \\
\left(\text { days decade }^{-1}\right)\end{array}$} & \multirow[t]{2}{*}{$\begin{array}{l}\text { Thermocline } \\
\text { (m decade }^{-1} \text { ) }\end{array}$} \\
\hline & Epilimnion & Metalimnion & Hypolimnion & & \\
\hline \multicolumn{6}{|l|}{ Lake Biel } \\
\hline LB1 & 0.19 & 0.16 & 0.13 & 1.5 & -0.02 \\
\hline LB2 & 0.15 & 0.13 & 0.06 & 2.0 & -0.07 \\
\hline LB3 & 0.13 & 0.11 & 0.05 & 2.2 & -0.13 \\
\hline \multicolumn{6}{|c|}{ Lake Geneva } \\
\hline LG1 & 0.17 & 0.13 & 0.07 & 2.9 & -0.07 \\
\hline LG2 & 0.17 & 0.12 & 0.07 & 2.8 & -0.06 \\
\hline LG3 & 0.18 & 0.16 & 0.08 & 2.2 & -0.04 \\
\hline
\end{tabular}

(Fig. 6a-c). Predicted warming of LB depends strongly on the scenario used (Fig. 6d-f).

Similar to the predicted warming patterns for rivers (Sect. 3.1), both lakes showed seasonally varying warming patterns. Reduced warming corresponds with periods of high river discharge (Fig. 5a and b). This cooling effect occurs primarily in winter and midsummer, and focussed in depth to the level of river intrusion (Figs. D1b, $d$ and 7c-f). Model results showed a greater degree of fluctuations of the warming in LB than in LG. This probably results from the greater influence of the Aare on LB compared to that of the Rhône on LG, as LG has a longer hydraulic residence time. Scenario LB1, which excludes river intrusion, showed only limited seasonal variation in warming (Fig. C1c and e). According to these results, the closure of MNPP could offset climateinduced warming of LB by $\sim 25 \%$.

Model results show that enhanced warming of the epilimnion relative to the hypolimnion strengthens stratification (Fig. $7 \mathrm{~g}$ and $\mathrm{h}$ ). This enhances the duration of stratification (for both lakes $\sim+2$ days decade ${ }^{-1}$; Table 5) and slightly lifts the thermocline (in LB $\sim-0.1 \mathrm{~m} \mathrm{decade}^{-1}$ and in $\mathrm{LG} \sim-0.05 \mathrm{mdecade}^{-1}$; Table 5). We used the Schmidt (1928) stability $(S)$ to estimate the strength of stratification $\left(\mathrm{J} \mathrm{m}^{-2}\right)$

$S=\frac{g}{A_{0}} \sum_{z=0}^{z_{\max }}\left(z-z_{\mathrm{m}}\right)\left(\rho(z)-\rho_{\mathrm{m}}\right) A(z) \Delta z$.

Equation (7) incorporates gravity $\left(g=9.81 \mathrm{~m} \mathrm{~s}^{-2}\right)$, depth $(z)$, lake surface area $\left(A_{0}\right)$, horizontal cross section area $(A(z))$, lake density $(\rho(z))$, maximum depth $\left(z_{\max }\right)$, mean lake density $\left(\rho_{\mathrm{m}}\right)$, lake volume $(V)$ and volumetric mean depth $\left(z_{\mathrm{m}}\right)$ defined as

$z_{\mathrm{m}}=\frac{1}{V} \sum_{z=0}^{z_{\max }} z A(z) \Delta z$

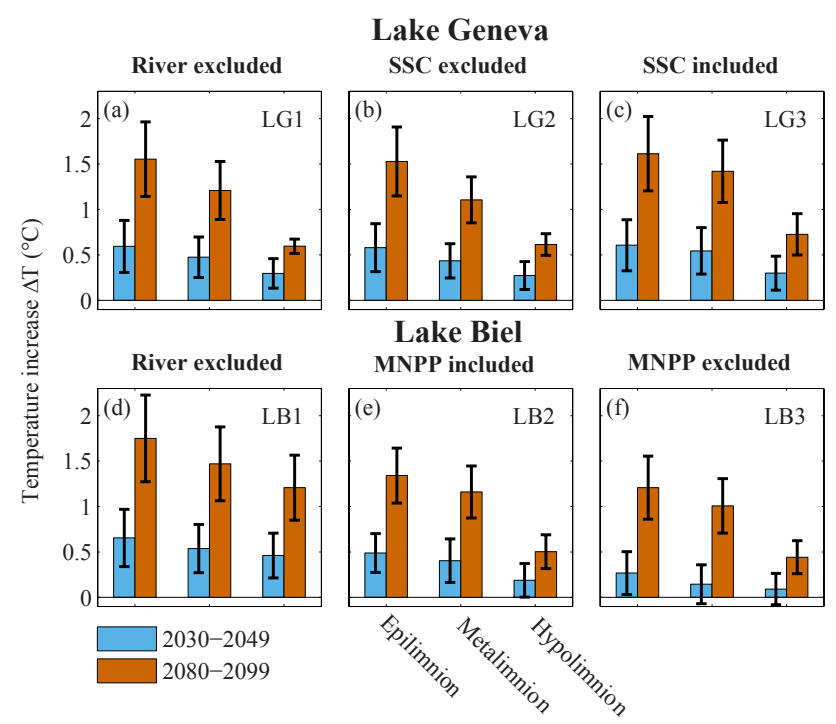

Figure 6. Temperature increase $\Delta T$ for near-future (blue) and farfuture (orange) time periods relative to reference period temperatures, displayed as mean (columns) and standard deviation (black bars) calculated from the nine basic model runs in the near-future and far-future scenarios. Epilimnion (left pair of columns), metalimnion (middle pair) and hypolimnion (right pair) in LG (a to c) and LB (d to f). Graphs represent river intrusion excluded (a and d), river-borne SSC included (c, e and f) and excluded (b). Mühleberg Nuclear Power Plant (MNPP) heat release included in (e) and excluded in (f) from near-future and far-future time periods but retained for the reference period.

The duration of stratification was determined by counting the days when temperature differed by more than $1^{\circ} \mathrm{C}$ between surface ( $2 \mathrm{~m}$ depth) and deep-water ( $280 \mathrm{~m}$ for LG; $50 \mathrm{~m}$ for LB) (Foley et al., 2012). The maximum water column stability expression $N^{2}=-(g / \rho) \Delta \rho(z) / \Delta z\left(\mathrm{~s}^{-2}\right)$ was used to determine the thermocline depth. 

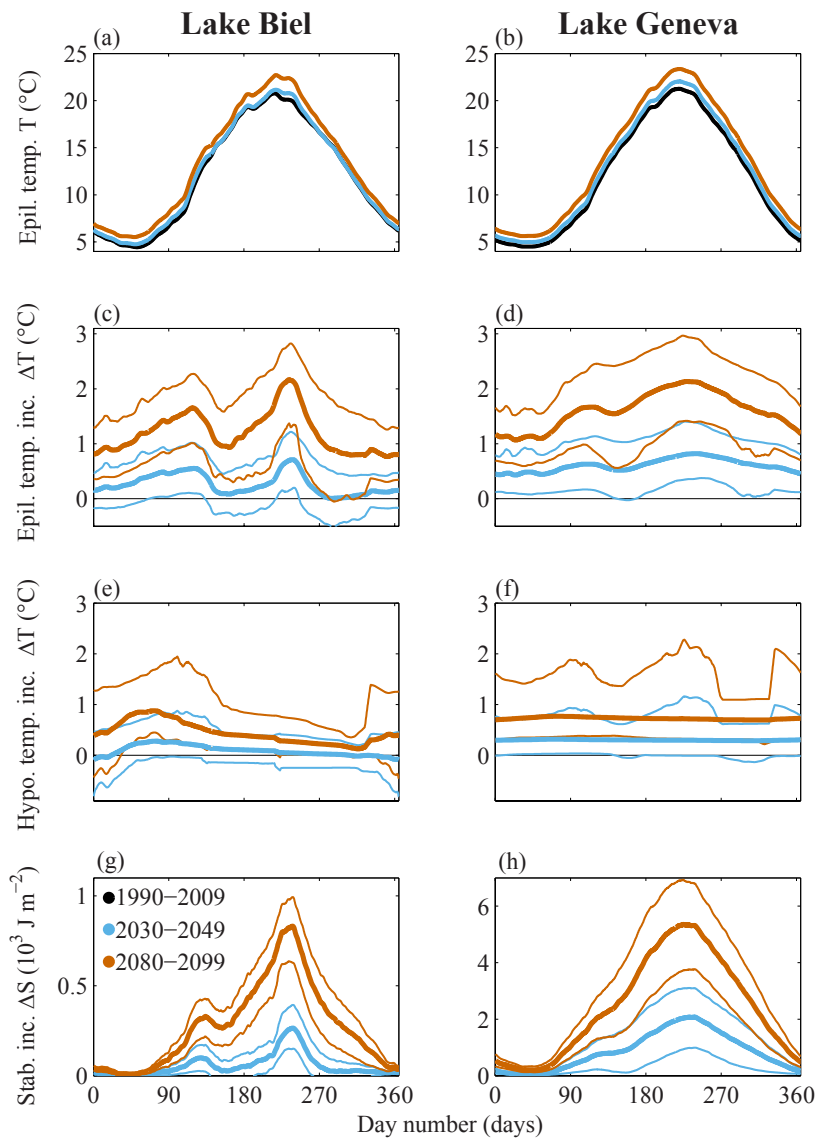

Figure 7. Modeled climate impact from scenarios LB3 (LB; a, c, e, g) and LG3 (LG; b, d, f, h) displayed as daily mean (thick lines) and maximum/minimum model values (thin lines) for near-future (blue, 2030-2049) and far-future (orange, 2080-2099) relative to the reference period (black, 1990-2009). Anthropogenic MNPP heat input entering LB has been excluded from near-future and far-future time periods but retained for the reference period. Temperature $T$ (a and $\mathbf{b}$ ), increase in temperature $\Delta T$ in epilimnion (c and $\mathbf{d}$ ) and hypolimnion (e and $\mathbf{f}$ ) as well as increase in stability $\Delta S$ (g and $\mathbf{h})$.

The river intrusion depth is dependent on water density (temperature and SSC are dominant; dissolved solids are negligible). The Rhône is colder (Fig. 5c and d) and carries more suspended sediment (Fig. 5g and h) than the Aare. Reference period results showed that the Rhône intruded in LG at greater depths relative to depths of the Aare intrusion into LB (Figs. 8 and D1). Given the future change in river temperature and SSC, intrusion patterns will thus change as the densities of both the Aare and Rhône increase and decrease during respective winter and summer seasons (Sect. 3.1). This explains model results showing respective deeper and shallower intrusions during winter and summer for both rivers (Fig. D1).

Model results show that warming of the Rhône generally diminishes the amount of river water penetrating beyond
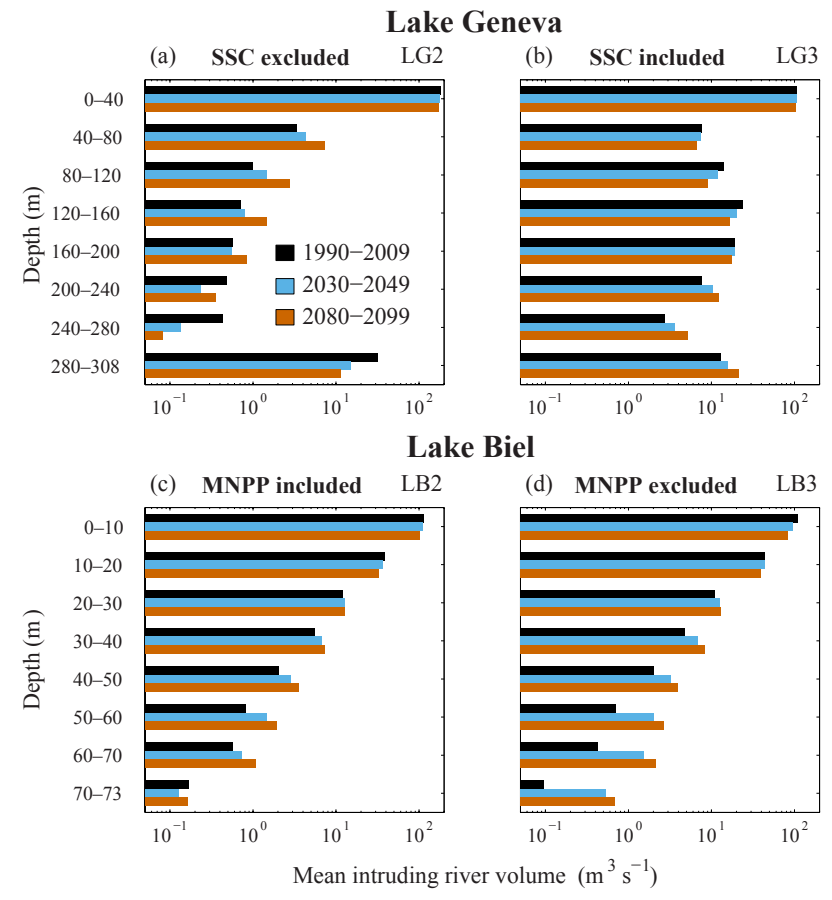

Figure 8. Modeled climate impact on intruding river volumes. Reference (black), near-future (blue) and far-future (orange) time periods for LG (a, b) and LB (c, d), including (b-d) and excluding (a) river-borne SSC and MNPP heat input included in (c) or excluded (d) from near- and far-future time periods but retained in the reference period.

$200 \mathrm{~m}$ depth in LG (Fig. 8a). Enlarged river flow in winter enhances SSCs and counteracts heating, thereby increasing the amount of river water intruding beyond $200 \mathrm{~m}$ depth (nearfuture $\sim 30 \%$; far-future $\sim 65 \%$; Fig. $8 \mathrm{~b}$ ). The difference in winter heating for the Aare and LB epilimnion (Figs. 5c, e and 7c) generally increased the amount of water penetrating into the hypolimnion (Fig. 8c). Decommission of the MNPP enhances temperature differentials between LB and the Aare, thereby increasing the amount of water reaching past $30 \mathrm{~m}$ in LB (near-future $+\sim 80 \%$; far-future $+\sim 120 \%$; Fig. 8 d). In summary, the change in river discharge regime for the Aare and Rhône results in respective increase and decrease in winter and summer water density, resulting in a summer to winter shift of the amount of river water penetrating deeper than the metalimnion for both lakes.

\section{Discussion}

\subsection{Rivers}

Increases in air temperature expected from climate change modify tributary runoff. Less water is predicted to be bound in snow and ice at high elevation during winter and spring/summer floods will occur earlier (CH2011, 2011; 
FOEN, 2012). The changed river discharge regime, appearing as increased flow in winter and decreased flow in summer (Fig. 5a and b), amplifies the increase and decrease in river temperature during respective summer and winter periods (Fig. 5e and f). Amplification results from (i) a smaller flow volume requiring less energy to heat and (ii) lower flow velocities which extend heat exposure. The PREVAH model predicts that the future discharge of the Aare in summer will be $\sim 20 \%$ less than summer discharge in the Rhône. These results therefore suggest that the Aare summer conditions will be more impacted by climate change than the Rhône summer conditions (Fig. 5e and f).

Model results concerning discharge-dependent responses to climate-induced warming were consistent with previous findings reported by Isaak et al. (2012) and van Vliet et al. (2013). The river temperature increases predicted by this study $\left(+0.10^{\circ} \mathrm{C}\right.$ decade $^{-1}$ for the Aare and $+0.07^{\circ} \mathrm{C} \mathrm{decade}^{-1}$ for the Rhône) were much smaller than past observed warming rates $\left(0.34{ }^{\circ} \mathrm{C} \mathrm{decade}^{-1}\right.$ for the Aare and $0.21^{\circ} \mathrm{C} \mathrm{decade}^{-1}$ for the Rhône; Hari et al., 2006). These differences may reflect contrasting reference periods with past observations conducted from 1971 to 2001 and modeled observations addressing 1990 to 2099. Past observations also incorporate effects of solar brightening during the 1980s (Fink et al., 2014a; Sanchez-Lorenzo and Wild, 2012; Wild et al., 2007), which led to additional warming of air and water.

Climate change effects aside, MNPP decommissioning in 2019 is predicted to decrease the temperature in the Aare by up to $4.5^{\circ} \mathrm{C}$ at station no. 2085 (Råman Vinnå et al., 2017). The cooling effect of this plant closure primarily affects winter conditions when climate-change-induced warming is weaker and river flow is lower (Fig. 5e). The heating of the Aare and LB by MNPP heat emissions equates to approximately 1 decade of climate-induced warming of lake surface waters (O'Reilly et al., 2015; Råman Vinnå et al., 2017). This result highlights the role of point source thermal contributions in local climate impact assessments.

The amount of suspended sediment carried by rivers depends on both discharge and the amount of erodible sediment in the watershed (Fink et al., 2016). We used a supply-based sediment rating model subjected to a changing discharge regime to examine seasonal changes in suspended sediment for both the Aare and Rhône (Fig. $5 \mathrm{~g}$ and h). Consistent with previous findings reported by Pralong et al. (2015), we predict an increase in SSC during winter and decrease in SSC in summer. This is caused by two phenomena associated with increased river discharge: (i) amplified river bed erosion linked to increased intensity of high discharge events carrying enhanced volumes of SSC and (ii) increase in the sediment available for erosion in the river catchment due to enhanced supply at low flow velocities.

Figure 4 and Table 2 show that the SSC model gives robust results for the Rhône (coefficient of determination $R^{2}=0.68$ from 2013 to 2014) but not for the Aare $\left(R^{2}=0.06\right.$ from
2013 to 2014). The Aare includes several sediment-trapping reservoirs/lakes upstream of station no. 2085. Thus, peaks in SSC at station no. 2085 do not reflect watershed-scale discharge events (Fig. 4) but rather local precipitation and discharge events in the headwaters of a tributary (Saane River) to the Aare (Fig. 2). This tributary hosts few sediment traps and contributes $\sim 34 \%$ of the downstream flow at station no. 2085. Given the limited impact of SSC on the Aare water density, models show only negligible impact on river intrusion depth and corresponding intruding volumes (Figs. 8c, $\mathrm{B} 1 \mathrm{c}$, e and D1c). The lower reaches of the Rhône are not dammed, thus adhering more directly to model assumptions and giving clearer results (Fig. 4).

High SSC events are usually associated with extreme floods (Fink et al., 2016), which are predicted to vary in alpine lake catchments with on-going climate change (Glur et al., 2013). The lack of constraints on extreme precipitation events introduces uncertainty into future flood frequency and magnitude predictions $(\mathrm{CH} 2011,2011)$. Shifts in river discharge regimes also depend on the amount of water bound in snow and ice as well as on the timing of spring/summer melt. Future climate scenarios predict that $\sim 30 \%$ of the glacier mass will remain in the Aare and the Rhône catchments by the end of the 21 st century (FOEN, 2012). Glacial meltwater is thus expected to continue to supply the Aare and Rhône throughout the time frames considered in this study. We thus assumed that the flood frequency remained unchanged, while the amplitude of the floods was adjusted in the future according to river discharge regime shifts predicted by FOEN (2012).

\subsection{Lakes}

All model scenarios showed that increased air temperature leads to warming of both lakes, especially of the epilimnion (Table 5, Fig. 6). Piccolroaz et al. (2015) showed that an increase in lake stability and earlier onset of stratification causes warming of surface waters due to the smaller volume undergoing warming and diminished heat transfer to the hypolimnion. The lake model used here showed an increase in stratification strength and a lengthening of the stratified period in both lakes (Table 5; Fig. 7g and h). Our results thus consistently support previous findings for LG reported by Foley et al. (2012), O'Reilly et al. (2015) and Schwefel et al. (2016).

Seasonal variations in warming of both epilimnion and hypolimnion (Fig. 7a-f) surpassed the seasonality of applied changes in air temperature (Fig. 2a). The model showed a decrease in warming during winter and midsummer, which corresponds to time periods of high river discharge from the main tributaries (Fig. 5a and b). This cooling effect was more effective for LB than for LG (Fig. 7) and appeared in all scenarios except for LB1 and LG1 (Fig. C1), both of which exclude coupled river effects. The extended seasonal variation in climate warming is thus driven by river discharge volume 
and temperature trends (Figs. 5 and 7). This response applies to aquatic systems in which a difference exists in temperature and heating regimes between rivers and lakes, but does not appear to affect water bodies with uniform temperature/heating regimes. Our results thus supports the hypothesis put forward by Zhang et al. (2014), stating that climate warming of lakes might be reduced and even reversed by addition of external water.

To investigate this effect, we varied the hydraulic residence time of LB and LG, while holding all other factors constant (Fig. 9). We implemented a stepwise reduction in LG size (to $1 / 80$ of its original volume), simultaneously reducing hypsographic area but keeping maximum depth unchanged. Similar adjustments were made to LB to obtain corresponding hydraulic residence times. This stepwise approach required 972 additional model runs. These iterations showed that river water had to be cooler than lake water in order to generate a dampening effect for climate warming (Fig. 9a and d). Deep penetrations by large riverine volumes increase the cooling of the hypolimnion (Fig. 9b). The climate dampening effect is suppressed when river and epilimnion temperature are similar. MNPP thermal input creates such conditions in the Aare and therefore largely counteract the river cooling effect of the Aare on LB (Fig. 9c). For shorter residence times $(<\sim 1000$ days), rivers can exert influence if a significant temperature difference exists between river and lake waters. For longer residence times ( $>\sim 1000$ days), tributaries cannot significantly offset climate effects in downstream water bodies.

Climate-induced warming of lakes (Schwefel et al., 2016), along with changing frequency or intensity of deep penetrating flood events (Fink et al., 2016) may curtail oxygen supply to deep lakes. Recent flood analysis has also indicated that input of river-borne organic matter increases respiration, causing a paradoxical net oxygen reduction within the intruding layer (Bouffard and Perga, 2016). Models showed respective winter increase and summer decrease in river water density relative to lake stability. This creates summer to winter seasonal shifts in deep intrusion dynamics for both lakes (Fig. D1), causing a net annual increase in the river water penetrating to deeper parts of both lakes (Fig. 8). An increase in Rhône SSC in winter represented the primary driver in LG (Figs. 8a, b and D1a, b), while the dominant factor in LB was Aare river temperature, which cooled in winter by increased discharge and removal of MNPP heat (Figs. 8c, d and D1c, d).

Fink et al. (2016) also found evidence that climate change will cause diminished deep river intrusion events in summer and enhanced intrusion in winter. They predicted an annual decrease in the amount of river water reaching the deepest parts of Lake Constance. The tributaries considered here differ from the Rhine River investigated by Fink et al. (2016) primarily in terms of temperature. The Rhône catchment for example rests at a mean elevation of $2127 \mathrm{~m}$ and includes greater glacial coverage $(11 \%)$, whereas the Rhine
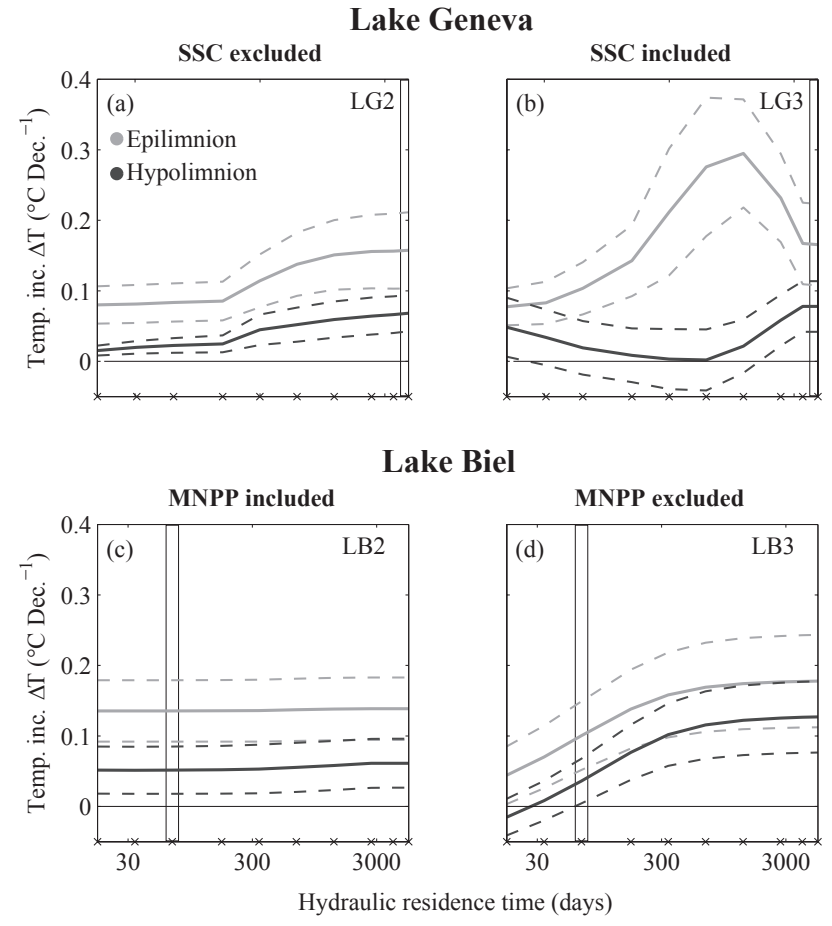

Figure 9. Variation in lake hydraulic residence times (changed lake volume) in response to modeled temperature increase $(\Delta T)$ in the epilimnion (grey) and hypolimnion (black) displayed as decadal mean (solid line) and standard deviation (dotted line) for LG (a, b) and LB (c, d). River-borne SSC included (b) and excluded (a, c and d), MNPP heat input included in (c) and excluded (d) from near-future and far-future time periods but retained for the reference period. Black x's mark modeled lake residence times, while full-height black rectangles mark the lakes' presentday residence times.

catchment has a mean elevation of $1771 \mathrm{~m}$ and only $1 \%$ glacial coverage (www.hydrodaten.admin.ch). The closure of the MNPP and associated temperature decrease contribute to increase the volume/frequency of deep intrusions (Fig. 5). While Fink et al. (2016) focused primarily on flood frequencies, our models emphasized river discharge regimes and interacting river and lake temperature regimes. The annual increase in river penetration to depth predicted by our models suggests future increase in deep-water oxygen supply in similar tributary-lake systems. This prediction applies mainly to meromictic lakes such as LG. Analogous effects in holomictic lakes such as LB, which mix completely each winter, are less significant. Similar to findings of Fink et al. (2016), our models indicate that deep-water oxygen conditions will worsen during strongly stratified conditions due to seasonal shifts in deep river intrusions from summer to winter. Concluding, as river water density increases in winter, the volume of those intrusion events, which occurred in the reference period, will increase in the future. Likewise, high discharge 
events, which were previously unable to penetrate into the deep, are likely to do so in the future.

\subsection{Model reliability}

Predictions concerning the effect of climate change on rivers and lakes depend on (i) the choice of emission scenario, (ii) the accuracies of models linking climate to hydrology and climate to heat fluxes and (iii) natural variability of the system being investigated (Raymond Pralong et al., 2015). This section describes uncertainties and limitations of our approach.

Results of long-term forecasts (beyond 2050) depend strongly on representations of global greenhouse gas emission scenarios (FOEN, 2012). Given the uncertainties in future global climate policy, we chose a median scenario, which falls between the best (e.g., RCP3PD) and the worst case scenarios (e.g., A2) in terms of greenhouse gas emissions. A1B assumes a peak population at mid-century, balanced use of renewable and fossil fuels and rapid introduction of new technologies.

Estimates of future air temperatures and river discharge were obtained from a combination of regional climate models (RCMs; CH2011, 2011; FOEN, 2012). Uncertainties associated with individual RCMs were offset by combined forecasts from multiple-model chains. Numerous studies have performed detailed evaluations of uncertainty in air temperature and river discharge under established emission scenarios (RCP3PD, A1B, A2) and accounting for globalregional climate model interactions (Addor et al., 2014; Bosshard et al., 2011, 2013; CH2011, 2011).

The degree of accuracy with which model input parameters represent future conditions determines the accuracy of model predictions. We therefore ran the river temperature model with varying parameters to evaluate model sensitivity (Table 1) for different yet similar datasets. The air2stream parameter $a_{1}$ showed the greatest degree of sensitivity, varying within 3 orders of magnitude. The $a_{1}$ parameter, however, does not respond to variations in river discharge or air temperature (Eq. 1), which limits its sensitivity to climatic input data. The other parameters ( $a_{2}$ to $a_{8}$ ) varied only within 1 order of magnitude (Table 1). The SSC model gives better results for the Rhône (coefficient of determination $R^{2}=0.68$ from 2013 to 2014) than for the Aare $\left(R^{2}=0.06\right.$ from 2013 to 2014). Dams and reservoir infrastructure upstream of station no. 2085 along the Aare dampen sediment transport events and decouple them from regional discharge events (see above; Fig. 4). Given the relatively minor effect of SSC on the Aare water density, variation in the input parameter does not influence river intrusion depths (Figs. B1e-f and D1c-d). As with other vertical, one-dimensional models, SIMSTRAT cannot account for lateral heterogeneities in lakes. This inherent weakness in model design, however, does not significantly diminish the accuracy of model pre- dictions concerning LB and LG (Råman Vinnå et al., 2017; Schwefel et al., 2016).

Of special importance for climate research in lakes is the sensitivity of models to shifts in the heat budget. Forcing parameters of importance, besides air temperature, include wind speed, solar irradiance, vapor pressure and light absorption. The sensitivity of SIMSTRAT to variable forcing has previously been established for lakes in Switzerland. Schmid and Köster (2016) demonstrated how solar brightening from 1981 to 2013 increased Lake Zürich surface warming comparable to heating by increased air temperature. Schwefel et al. (2016) revealed strengthening of the thermocline and decrease in the mean lake temperature by increased light absorption in LG, whereas a decrease in absorption had the reverse effect. As of yet, reliable predictions of wind speed, irradiance and vapor pressure under future climate conditions are not available for Switzerland (CH2011, 2011). Therefore, we use long-term (1981 to 2013) data from station no. 8100 (Fig. 2) as guidance for potential annual atmospheric forcing trends (Fig. A6; Table 6).

The sensitivity of SIMSTRAT was tested in LG by applying these trends, individually and combined, to the reference period. The increasing trend in air temperature was included for comparison, while no trend could be identified in cloud cover which was excluded. The decreasing trend in wind speed cooled the lake, while the increasing trend in irradiance and vapor pressure heated the lake comparable to air temperature (Table 6). By combining all trends, we obtained similar warming of the $\mathrm{LG}$ epilimnion $\left(\sim+0.38^{\circ} \mathrm{C} \mathrm{decade}^{-1}\right)$ as observed over land $\left(+0.38^{\circ} \mathrm{C} \mathrm{decade}^{-1} ; 1985-2002\right.$; Wild et al., 2007) and globally in lakes $\left(\sim 0.34^{\circ} \mathrm{Cdecade}^{-1} ; 1985-\right.$ 2009; O'Reilly et al., 2015) as well as monitored in LG surface waters $\left(\sim+0.51^{\circ} \mathrm{C}\right.$ decade $^{-1}, 1983-2000$; Gillet and Quétin, 2006). The historical effect of increased air temperature caused $\sim 40$ to $\sim 70 \%$ of the heating in the epilimnion/metalimnion and $\sim 240 \%$ in the hypolimnion.

Here we include predictions of future temperature and precipitation. The extrapolation of observed atmospheric trends into the future is outside the scope of the present study. Yet, we expect our lake water temperature predictions for the near-future and far-future scenarios to underestimate the total heating in shallow water and overestimate warming of deep-water. Nonetheless, the solar brightening trend observed over Switzerland from 1980 to 2000 , caused by a decrease in atmospheric aerosols, will not continue into the future (Sanchez-Lorenzo and Wild, 2012), thereby reducing the uncertainty of our predictions.

In this study we assumed that glacial meltwater feeding both the Aare and Rhône in summer will not disappear within the time frames considered. Loss of glacial sources would modify the discharge regime, especially in summer, which would affect accuracy of temperature, SSC and intrusion depth estimates. However, as stated in Sect. 4.1, FOEN (2012) predicts that the Aare and Rhône catchments will retain $30 \%$ of their glacial masses by the year 2100 . 
Table 6. Observed trends in atmospheric forcing (1981 to 2013) at station no. 8100 (Fig. 2) per decade, and modeled temperature increase in Lake Geneva (LG) with forcing trends applied to the reference period (1990 to 2009).

\begin{tabular}{|c|c|c|c|c|}
\hline \multirow[t]{2}{*}{ Parameter } & \multirow[t]{2}{*}{ Observed atmospheric trend } & \multicolumn{3}{|c|}{$\begin{array}{l}\text { Modeled LG temperature change } \\
\qquad\left({ }^{\circ} \mathrm{C} \text { decade }^{-1}\right)\end{array}$} \\
\hline & & Epilimnion & Metalimnion & Hypolimnion \\
\hline Wind speed & $-0.097\left(\mathrm{~m} \mathrm{~s}^{-1} \mathrm{decade}^{-1}\right) ;-5.7\left(\% \mathrm{decade}^{-1}\right)$ & -0.022 & -0.149 & -0.089 \\
\hline Shortwave irradiance & $3.8\left(\mathrm{~W} \mathrm{~m}^{-2} \mathrm{decade}^{-1}\right) ; 2.6\left(\% \mathrm{decade}^{-1}\right)$ & 0.134 & 0.131 & 0.027 \\
\hline Vapor pressure & $0.26\left(\mathrm{mbar}_{\mathrm{decade}}{ }^{-1}\right) ; 2.6\left(\% \mathrm{decade}^{-1}\right)$ & 0.122 & 0.085 & 0.050 \\
\hline Air temperature & $0.40\left({ }^{\circ} \mathrm{C}\right.$ decade $\left.^{-1}\right) ; 3.7\left(\%\right.$ decade $\left.^{-1}\right)$ & 0.149 & 0.101 & 0.017 \\
\hline All combined & & 0.379 & 0.147 & 0.007 \\
\hline
\end{tabular}

These predictions support assumptions concerning the Aare and Rhône discharge regimes used here. Point sources/sinks of anthropogenic heat can affect inland water bodies response to climate change, as shown by the MNPP effects described here. Other changes in catchment management, such as hydropower damming would also alter river discharge regimes and by extension, temperatures, SSCs and deep-water renewal (Fink et al., 2016). Thus, the correctness of future climate change predictions depends on adequate accounting of regional anthropogenic factors affecting physical processes in the system under investigation.

\section{Conclusion}

Aquatic processes in lakes are the result of regional forcing and the upstream catchment environment. This study investigated the impact of climate change on inland waters by propagating climatic inputs through integrated fluvial-lacustrine systems. We fed predicted future climatic data into models for two connected river and lake systems in order to evaluate downstream thermal responses and how river discharge regime shifts might affect deep-water renewal in the lakes. Climate data propagated through discharge-dependent river temperature and SSC models, which were coupled to a onedimensional lake model. We applied this approach for the two peri-alpine lakes Biel and Geneva.

The models showed that climate warming of rivers is enhanced in summer and diminished in winter due to future river discharge regimes with decreased flow in summer and increased flow in winter. This climate-caused alteration of the flow regime likewise increase and decreases the river-borne suspended sediment load in winter and summer, respectively.

Both lakes showed large seasonal temperature increases that could not be solely explained by climate-related (predicted) increases in air temperature. Instead, the lakes experienced a cooling effect associated with upstream tributaries, where responses to increasing future air temperatures differed from that of the lakes. The smaller Lake Biel showed stronger response to this repressive effect of climate warming compared to the larger Lake Geneva. Predicted changes in Lake Biel strongly depend on the removal of upstream anthropogenic thermal emission into the Aare River. Local anthropogenic point sources of heat can thus rival climate change in their influence on lakes. This damping of climate warming depends on the lakes hydraulic residence times and requires adequate river/lake temperature differences. Our models indicate that tributaries can exert a system-wide influence on lakes with hydraulic residence times less than $\sim 1000$ days. Lake systems with longer residence times are resistant to tributary effects but may respond on a local level.

The combination of changes in river SSC and differential lake/river temperature/warming result in a seasonal shift of deep-water penetration (by rivers) into lakes. The volume of river water penetrating to deeper parts of lakes specifically decreases in summer and increases in winter. Higher rates of deep-water renewal can in turn enhance reoxygenation of the deepest reaches of lakes, which may otherwise experience lower oxygen concentrations under climate change.

Data availability. CTD profiles are available from the Office of Water Protection and Waste Management of the Canton of Bern (GBL/AWA) at: http://www.bve.be.ch/bve/ de/index/wasser/wasser/messdaten.html (GBL/AWA, 2017). Meteorological data are available from the Swiss Federal Office of Meteorology and Climatology (MeteoSwiss) at: http://www.meteoswiss.admin.ch/home/services-and-publications/ beratung-und-service/data-portal-for-teaching-and-research.html (MeteoSwiss, 2017). Tributary data are available from the Hydrology Department of the Swiss Federal Office for the Environment (FOEN) at: www.hydrodaten.admin.ch (FOEN, 2017a).

Future river discharge predictions are available from the Climate Change and Hydrology in Switzerland (CCHydro) project at: http: //www.bafu.admin.ch/umwelt/index.html?lang=en (FOEN, 2017b). DHM25 model bathymetry data are available from the Swiss Federal Office of Topography (SwissTopo) at: https://shop.swisstopo. admin.ch/en/products/height_models/dhm25 (SwissTopo, 2017). 


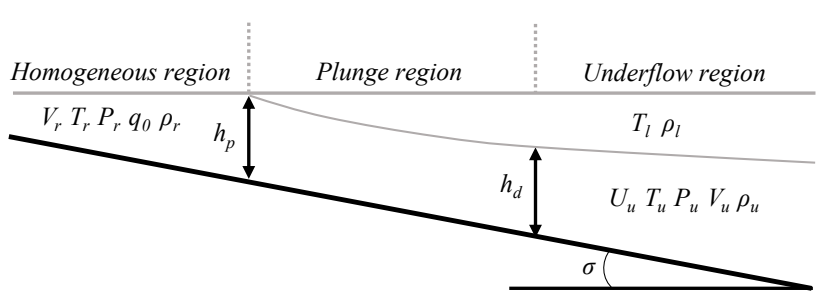

Figure A1. Illustration of river intrusion model.

\section{Appendix A: River intrusion model}

Figure A1 summarizes the river intrusion model. The depth where the river plume separates from the surface, the socalled plunge depth $\left(h_{\mathrm{p}}\right)$, depends on the slope angle $(\sigma)$, gravity $(g)$, coefficients $\left(S_{1}=0.25, S_{2}=0.75\right.$; Ellison and Turner, 1959), bed friction $\left(f_{\mathrm{t}}=0.02\right.$; Akiyama and Heinz, 1984), initial flow per unit width $\left(q_{0}\right)=V_{\mathrm{r}} / W_{\mathrm{r}}$ dependent on river discharge $\left(V_{\mathrm{r}}\right)$, river width $\left(W_{\mathrm{r}}=100 \mathrm{~m}\right.$ for the Aare and $W_{\mathrm{r}}=120 \mathrm{~m}$ for the Rhône) and the relative density difference $\left(\rho^{\prime}=\left(\rho_{\mathrm{r}}-\rho_{\mathrm{l}}\left(z_{1}\right)\right) / \rho_{\mathrm{l}}\left(z_{1}\right)\right)$ between the homogenous river $\left(\rho_{\mathrm{r}}\right)$ and lake $\left(\rho_{1}\right)$ with $z_{1}=$ surface.

$h_{\mathrm{p}}=e_{1}\left(\frac{f_{\mathrm{t}}}{\sigma(z) S_{2}} \frac{q_{0}^{2}}{g \rho^{\prime}}\right)^{1 / 3}+e_{2}\left(\frac{q_{0}^{2}}{S_{1} g \rho^{\prime}}\right)^{1 / 3}$

The level of initial plume entrainment is treated differently on a gentle versus a steep slope. This is controlled by the two coefficients $e_{1}$ and $e_{2}$.

$e_{1}=\left\{\begin{array}{l}1: \sigma\left(z_{1}\right)<\sigma_{\mathrm{c}} \\ 0: \sigma\left(z_{1}\right) \geq \sigma_{\mathrm{c}}\end{array}\right.$,

$e_{2}=\left\{\begin{array}{l}0: \sigma\left(z_{1}\right)<\sigma_{\mathrm{c}} \\ 1: \sigma\left(z_{1}\right) \geq \sigma_{\mathrm{c}}\end{array}\right.$,

where the critical slope angle $\sigma_{\mathrm{c}}=f_{\mathrm{t}} S_{1} / S_{2}$ distinguishes between gentle and steep slope designations. The initial height of the underflow $\left(h_{\mathrm{d}}\right)$ can then be written as

$h_{\mathrm{d}}\left(z_{1}\right)=h_{\mathrm{p}}(1+\gamma)$,

where $\gamma$ is the entrance mixing coefficient equal to $\sim 0$ for gentle slopes and increasing to larger values for steeper slopes. Here we find that a value of $\gamma=0.1$ provides best results. The initial underflow temperature $\left(T_{\mathrm{u}}\right)$, velocity $\left(U_{\mathrm{u}}\right)$, particle content $\left(P_{\mathrm{u}}\right)$ and volume $\left(V_{\mathrm{u}}\right)$ is consequently expressed as a function of ambient lake water temperature $\left(T_{1}\right)$, river temperature $\left(T_{\mathrm{r}}\right)$ and river particle content $\left(P_{\mathrm{r}}\right)$ in the homogenous region.
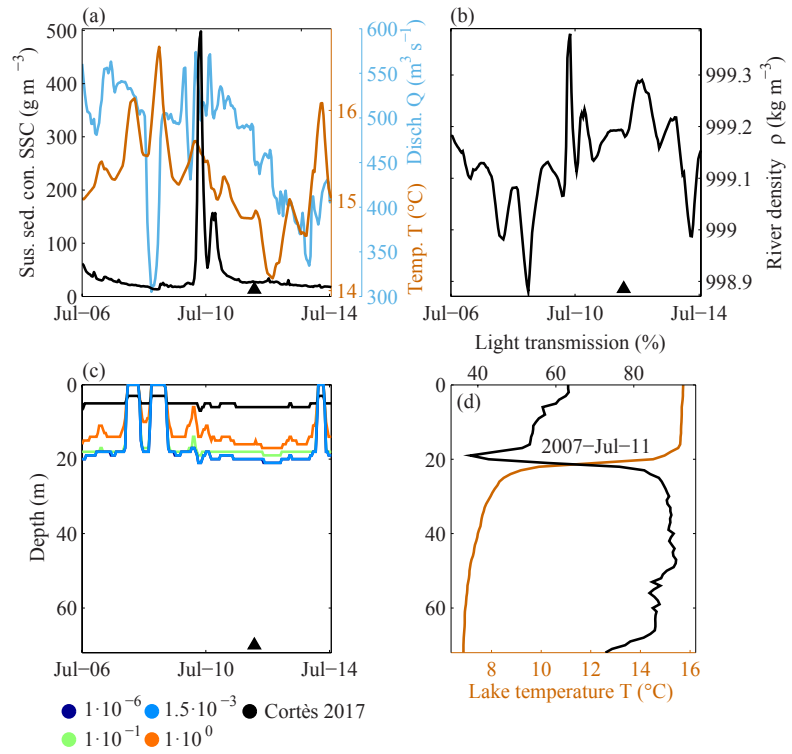

Figure A2. River intrusion entrainment sensitivity analysis for the LB/Aare system in July 2007. (a) SSC (black), temperature ( $T$; orange) and river discharge ( $Q$; blue) from Aare station no. 2085. (b) River density at station no. 2085 obtained from $T$ and SSC in (a). (c) River intrusion depth calculated from Appendix A with varying entrainment constant $\beta$ (Eq. A13); light green denotes the value used in this study; black indicate intrusion depth modeled as in Cortés et al. (2014). (d) Vertical measurements of $T$ and light transmission in LB for 11 July 2007. The triangles in (a)-(c) mark the time of the vertical profile in (d).

$T_{\mathrm{u}}\left(z_{1}\right)=T_{1}\left(z_{1}\right) \frac{\left(h_{\mathrm{d}}\left(z_{1}\right)-h_{\mathrm{p}}\right)}{h_{\mathrm{d}}\left(z_{1}\right)}+T_{\mathrm{r}} \frac{h_{\mathrm{p}}}{h_{\mathrm{d}}\left(z_{1}\right)}$,

$U_{\mathrm{u}}\left(z_{1}\right)=(1+\gamma) \frac{q_{0}}{h_{\mathrm{d}}\left(z_{1}\right)}$,

$P_{\mathrm{u}}\left(z_{1}\right)=P_{\mathrm{r}} \frac{h_{\mathrm{p}}}{h_{\mathrm{d}}\left(z_{1}\right)}$,

$V_{\mathrm{u}}\left(z_{1}\right)=V_{\mathrm{r}} \frac{h_{\mathrm{p}}}{h_{\mathrm{d}}\left(z_{1}\right)}$.

Once the plume has passed through the plunge region into the underflow region, we express $h_{\mathrm{d}}, U_{\mathrm{u}}, T_{\mathrm{u}}$ and $V_{\mathrm{u}}$ as

$$
\begin{aligned}
h_{\mathrm{d}}(z+1)= & h_{\mathrm{d}}(z)+E(z) \Delta x, \\
U_{\mathrm{u}}(z+1)= & U_{\mathrm{u}}(z) \frac{h_{\mathrm{d}}(z)}{h_{\mathrm{d}}(z+1)}, \\
T_{\mathrm{u}}(z+1)= & T_{1}(z) \frac{\left(h_{\mathrm{d}}(z+1)-h_{\mathrm{d}}(z)\right)}{h_{\mathrm{d}}(z+1)} \\
& +T_{\mathrm{u}}(z) \frac{h_{\mathrm{d}}(z)}{h_{\mathrm{d}}(z+1)}, \\
V_{\mathrm{u}}(z+1)= & V_{\mathrm{u}}(z) \frac{h_{\mathrm{d}}(z)}{h_{\mathrm{d}}(z+1)} .
\end{aligned}
$$

where $\Delta x$ is the horizontal distance between $z$ and $z+1$ and the entrainment factor $(E)$ is expressed as a function of 

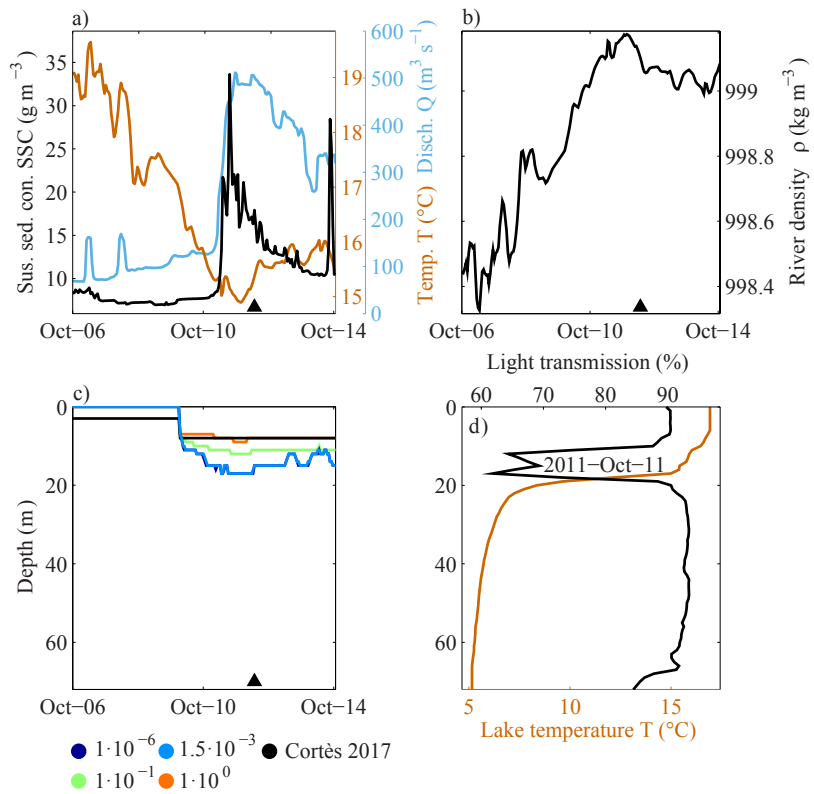

Figure A3. River intrusion entrainment sensitivity analysis for the LB/Aare system in October 2011. (a) SSC (black), temperature ( $T$; orange) and river discharge ( $Q$; blue) from Aare station no. 2085. (b) River density at station no. 2085 obtained from $T$ and SSC in (a). (c) River intrusion depth calculated from Appendix A with varying entrainment constant $\beta$ (Eq. A13); Light green denotes the value used in this study; black indicate intrusion depth modeled as in Cortés et al. (2014). (d) Vertical measurements of $T$ and light transmission in LB for 11 October 2011. The triangles in (a)-(c) mark the time of the vertical profile in (d).

the entrainment constant $(\beta=0.0015$; Ashida and Egashira, 1975) and the Richardson number $\left(R_{i}\right)$.

$$
\begin{aligned}
E(z) & =\frac{\beta}{R_{\mathrm{i}}(z)}, \\
R_{\mathrm{i}}(z) & =\frac{f_{\mathrm{t}}}{\sigma(z) S_{2}} .
\end{aligned}
$$

For $P_{\mathrm{u}}$, we include a sedimentation term as proposed by Syvitski and Lewis (1992), which depends on the removal rate $(r)$ and $\Delta t=\Delta x / U_{\mathrm{u}}(z)$.

$$
P_{\mathrm{u}}(z+1)=\frac{h_{\mathrm{d}}(z)}{h_{\mathrm{d}}(z+1)}\left(P_{\mathrm{u}}(z)-r e_{3} P_{\mathrm{u}}(z) e^{-r \Delta t} \Delta t\right)
$$

Sedimentation occurs only if the plume velocity drops below a critical settling velocity $\left(U_{\mathrm{c}}\right)$ subject to the parameter $e_{3}$ :

$e_{3}=\left\{\begin{array}{l}1: U_{\mathrm{u}}(z)<U_{\mathrm{c}} \\ 0: U_{\mathrm{u}}(z) \geq U_{\mathrm{c}}\end{array}\right.$

We set $U_{\mathrm{c}}$ equal to $0.46 \mathrm{~m} \mathrm{~s}^{-1}$ and $r$ equal to 4.7 day $^{-1}$ to represent medium-sized silt following Mulder et al. (1998). The plume travels downslope as long as the underflow plume
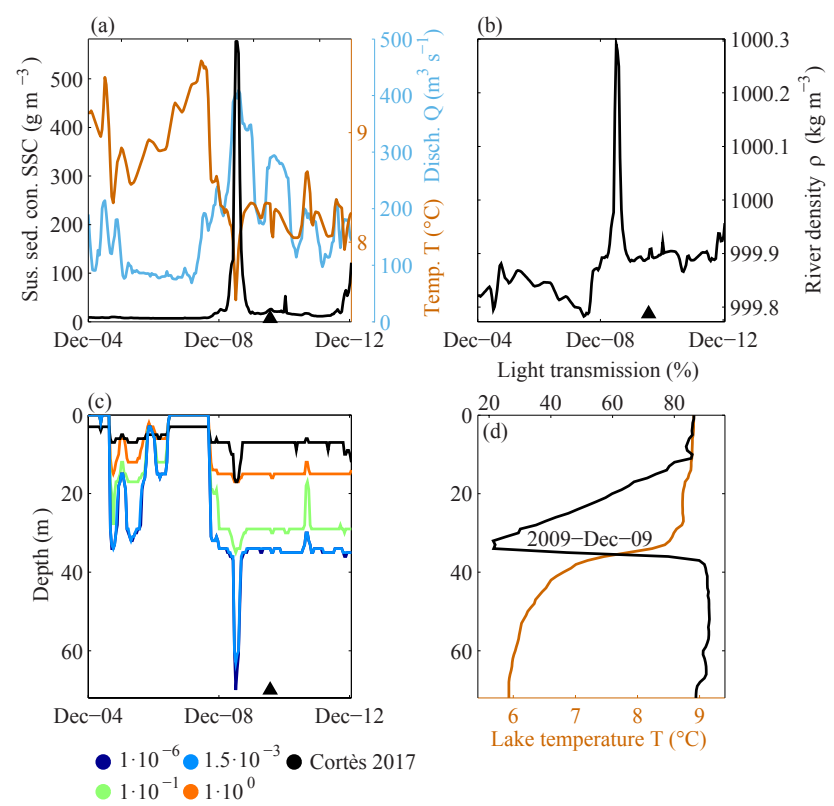

Figure A4. River intrusion entrainment sensitivity analysis for the LB/Aare system in December 2009. (a) SSC (black), temperature $(T$; orange) and river discharge $(Q$; blue) from Aare station no. 2085. (b) River density at station no. 2085 obtained from $T$ and $\mathrm{SSC}$ in (a). (c) River intrusion depth calculated from Appendix A with varying entrainment constant $\beta$ (Eq. A13); light green denotes the value used in this study; black indicate intrusion depth modeled as in Cortés et al. (2014). (d) Vertical measurements of $T$ and light transmission in LB for 9 December 2009. The triangles in (a)-(c) mark the time of the vertical profile in $(\mathbf{d})$.

density $\left(\rho_{\mathrm{u}}\right)$ exceeds $\rho_{\mathrm{l}}(z)$. Once $\rho_{\mathrm{u}} \leq \rho_{\mathrm{l}}(z)$, the plume raises from the slope and intrudes into the lake proper. The terms $T_{\mathrm{u}}$ and $V_{\mathrm{u}}$ were thus added to the lake model at this depth. Calculations excluded expressions for the settling of accumulated particles following plume intrusion, assuming that these exert only minor impacts on lake temperature and density.

The sensitivity of the river intrusion depth to entrainment of ambient water into the plume was tested by propagating a range of $\beta$ (Eq. A13) values from 1 to $1 \times 10^{-6}$ through model spaces composed of temperature, discharge and SSC data from the Aare (station no. 2085). Figures A2-A4 compare modeled intrusion depths to empirical estimates based on vertical temperature and light transmission data at the centre of $\mathrm{LB}\left(47^{\circ} 6^{\prime} \mathrm{N}, 7^{\circ} 11^{\prime} \mathrm{E}\right)$ collected shortly after major river intrusion events. Additionally, acoustic Doppler current profiler $(\mathrm{ADCP})$ measurements of river plume intrusions in $\mathrm{LB}\left(47^{\circ} 5^{\prime} \mathrm{N}, 7^{\circ} 12^{\prime} \mathrm{E} ; 2 \mathrm{~km}\right.$ from the Aare inlet) were used for a temporal sensitivity analysis of the intrusion model (Fig. A5). Comparison of the modeled intrusion depth with light transmission depth (whose minimum value represents a proxy for actual river intrusion depth) suggests that $\beta=0.0015$ offers an adequate representation of intru- 


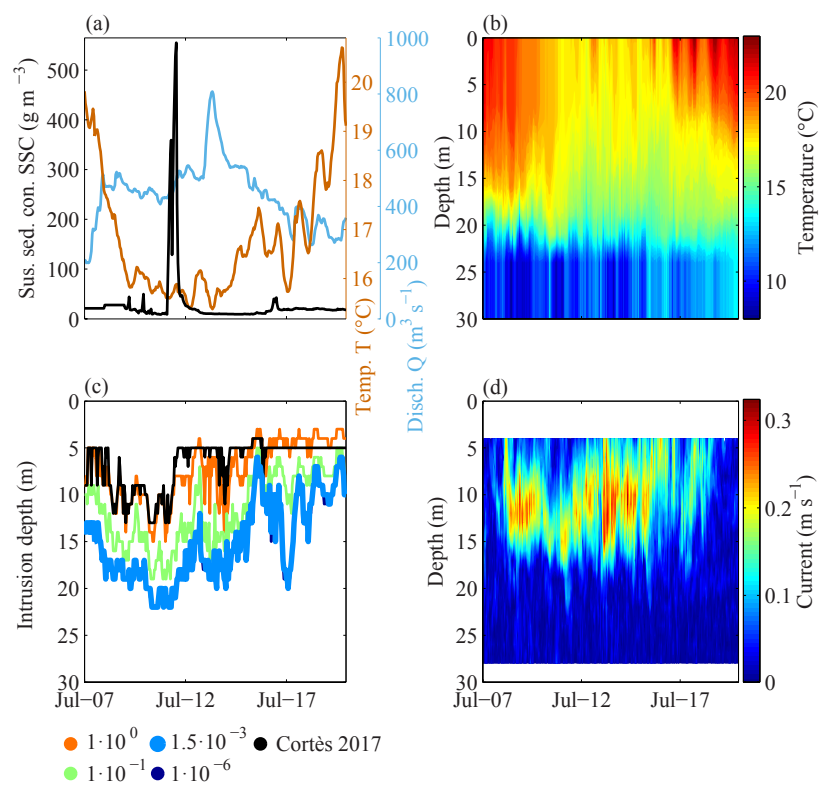

Figure A5. River intrusion entrainment sensitivity analysis for the LB/Aare system in July 2014. (a) SSC (black), temperature ( $T$; orange) and river discharge ( $Q$; blue) from Aare station no. 2085. (b) Lake temperature at M3 station. (c) River intrusion depth calculated as in Appendix A using river/lake density obtained from (a) and (b) with varying entrainment constant $\beta$ (colored, Eq. 18); light blue denotes the value used in this study; intrusion depth (black) calculated with method described in Cortés et al. (2014). (d) Current speed obtained from ADCP at M3 station; velocities $>0.15 \mathrm{~m} \mathrm{~s}^{-1}$ are associated with the passing river plume.

sion depth. Larger $\beta$ values generate intrusion depths shallower than the empirical reference points, whereas smaller $\beta$ values exerted only a minor impact on deepening the intrusion depth. The intrusion model used here was compared (Figs. A2c-A5c) to the intrusion scheme proposed by Cortés et al. (2014), which produced an inferior result for LB.
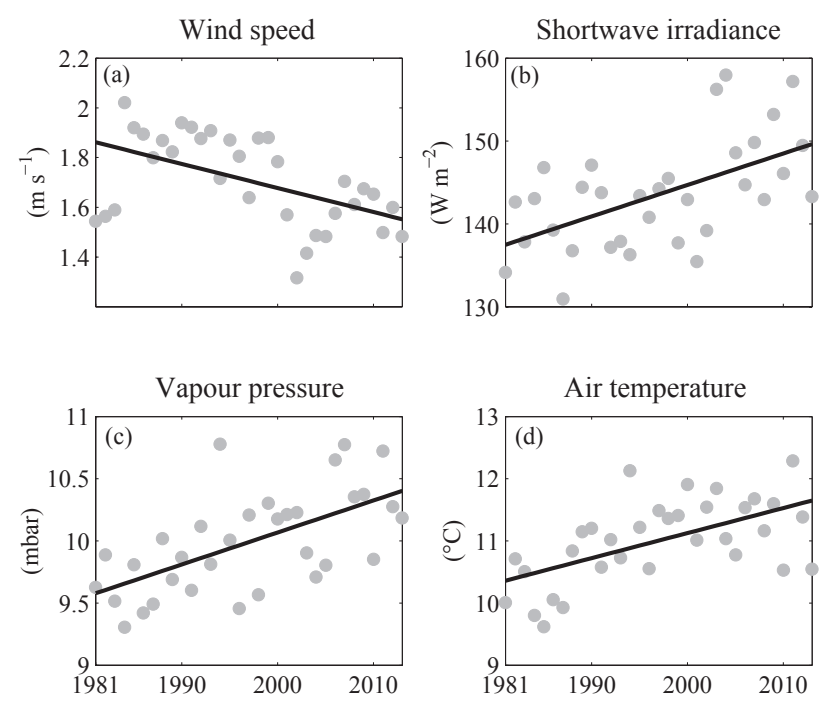

Figure A6. Annual atmospheric forcing (grey dots) of wind speed (a), shortwave radiation (b), vapor pressure (c) and Air temperature (d) at station no. 8100 (Fig. 2). The black line shows trends (Table 6). 


\section{Appendix B}
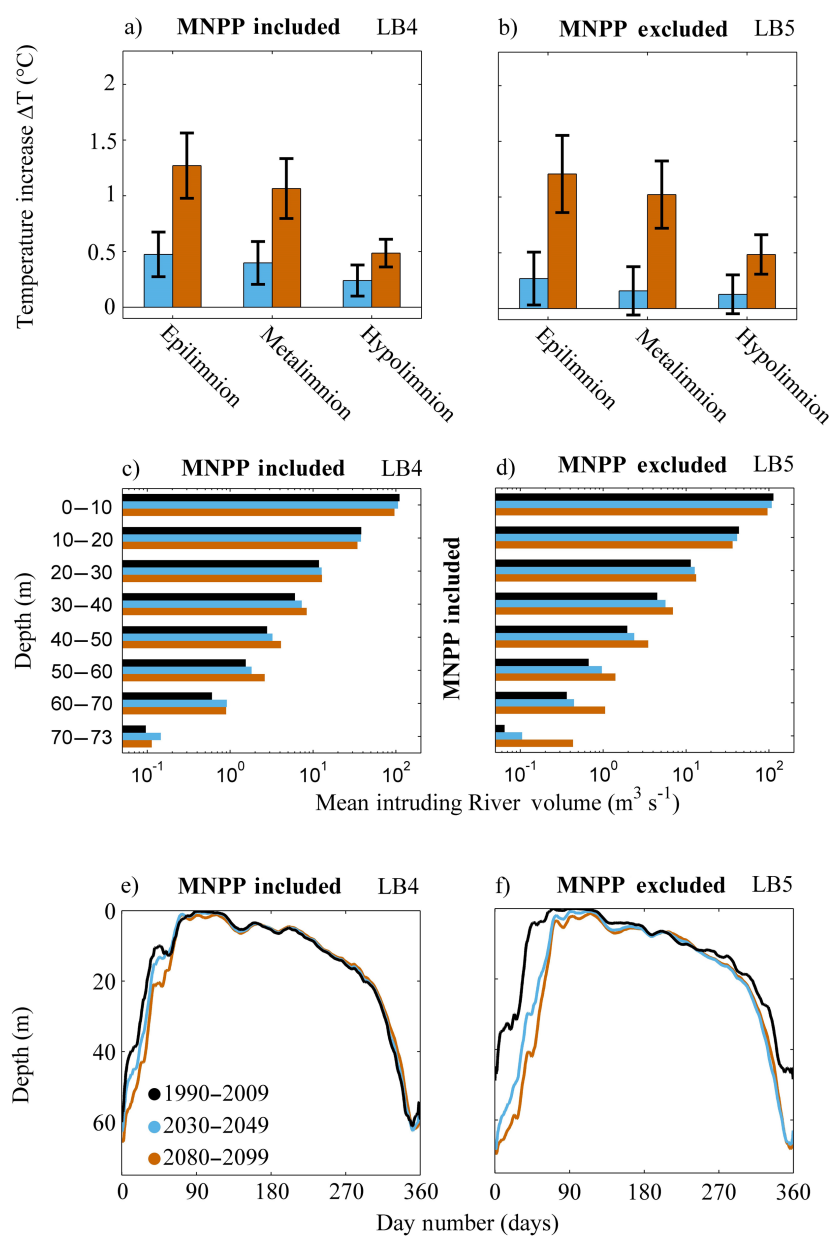

Figure B1. Modeled climate impact on LB excluding river-borne SSC. Temperature increase $\Delta T$ (a and b) displayed as means (bars) and standard deviations (black lines) in epilimnion (left bar group), metalimnion (middle bar group) and hypolimnion (right bar group); mean intruding river volume (c and $\mathbf{d}$ ) and mean river intrusion depth (e and f). MNPP thermal input included (a, c, e) or excluded (b, $\mathbf{d}, \mathbf{f}$ ) in near-future (blue) and far-future (vermilion) time periods but retained in the reference period (black).

\section{Appendix C}
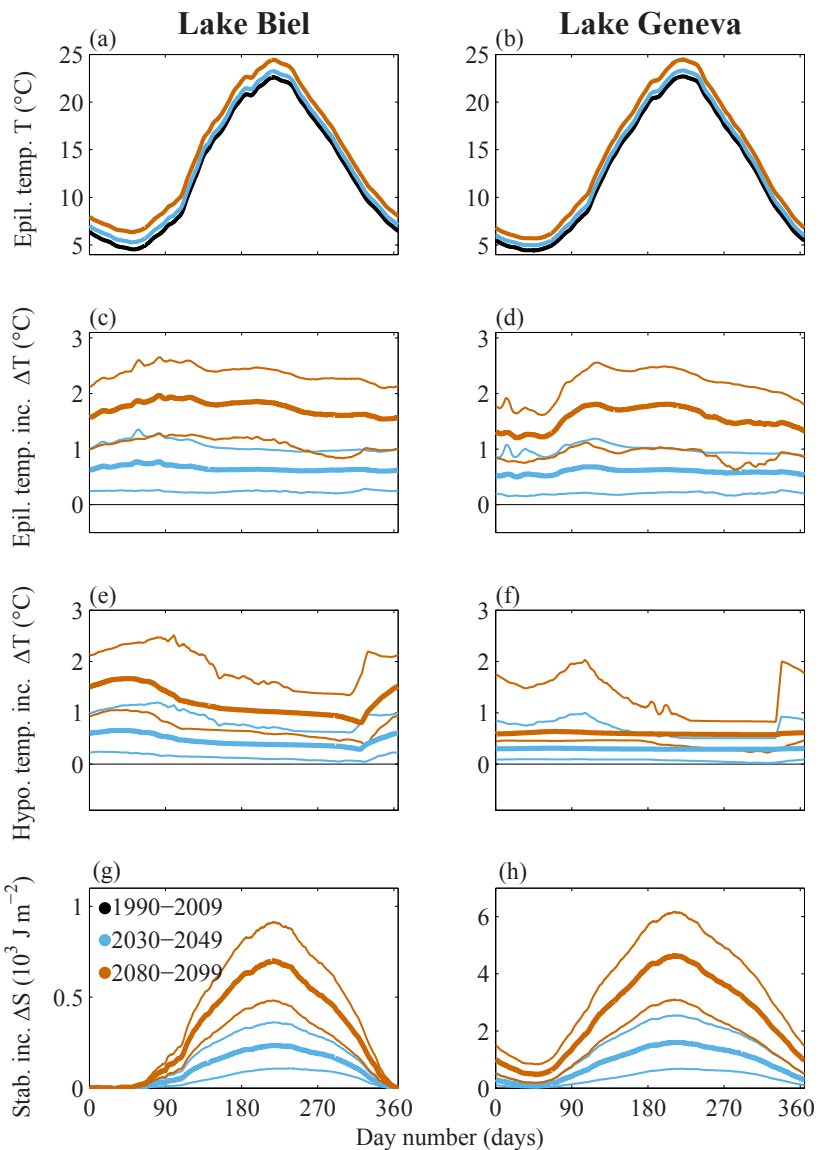

Figure C1. Modeled climate impact (river intrusion excluded) on LB (left column, scenario LB1) and LG (right column, scenario LG1) shown as daily mean (thick lines) and maximum/minimum model values (thin lines) for near-future (blue, 2030-2049) and farfuture (orange, 2080-2099) time periods relative to the reference period (black, 1990-2009). Temperature $T$ (a and b), temperature increase $(\Delta T)$ in the epilimnion ( $\mathbf{c}$ and $\mathbf{d})$ and hypolimnion (e and $\mathbf{f}$ ) as well as increase in stability $(\Delta S ; \mathbf{g}$ and $\mathbf{h})$. 


\section{Appendix D}

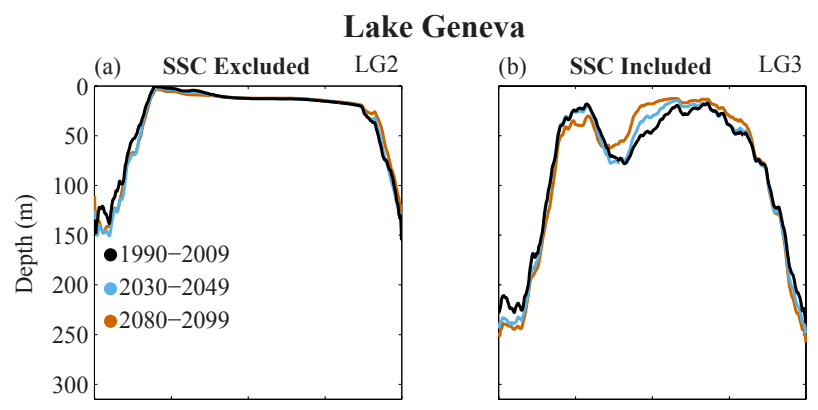

Lake Biel

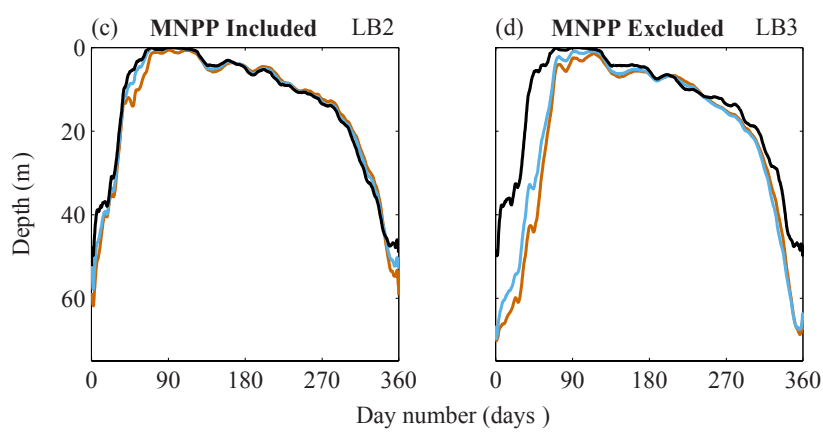

Figure D1. Modeled climate impact on mean river intrusion depth. Reference period (black), near-future (blue) and far-future (orange) time periods for LG (a-b) and LB (c-d) with (b-d) and without (a) river-borne SSC and MNPP thermal input included (c) or excluded (d) from near-future and far-future time periods relative to the reference period. 
Author contributions. LRV designed this study and preformed the modeling work; AW provided funding and supervision; DB contributed to the analysis of the result; GF adapted, calibrated and validated the SSC model; MZ provided river discharge predictions from the PREVAH model; all authors have contributed to the editing of this manuscript.

Competing interests. The authors declare that they have no conflict of interest.

Acknowledgements. This study is part of the "Hydrodynamic Modelling of Lake Biel for Optimizing the Ipsach Drinking Water Intake" project funded by Energy Service Biel (ESB). We are especially thankful to Andreas Hirt, Roland Kaeser and Markus Wyss for constructive collaboration. We thank the Office of Water Protection and Waste Management of the Canton of Bern (GBL/AWA) for providing their CTD profiles, the Swiss Federal Office of Meteorology and Climatology (MeteoSwiss) for providing meteorological data, the Hydrology Department of the Swiss Federal Office for the Environment (FOEN) for providing tributary data, the Climate Change and Hydrology in Switzerland (CCHydro) project for providing future river discharge predictions and the Swiss Federal Office of Topography (SwissTopo) for providing DHM25 model bathymetry data. We thank Bettina Schaefli at the University of Lausanne, Marco Toffolon and Elisa Calamita at the University of Trento, Nathalie Dubois at ETH Zurich, Robert Schwefel at EPFL Lausanne, Adrien Gaudard at Eawag and Stan Thorez at the University of Eindhoven for valuable insights. We furthermore thank Kei Ito (http://jfly.iam.u-tokyo.ac.jp/html/color_blind/) for valuable feedback on how to adapt our figures for color-blind readership.

Edited by: Anas Ghadouani

Reviewed by: two anonymous referees

\section{References}

Addor, N., Rössler, O., Köplin, N., Huss, M., Weingartner, R., and Seibert, J.: Robust changes and sources of uncertainty in the projected hydrological regimes of Swiss catchments, Water Resour. Res., 50, 7541-7562, https://doi.org/10.1002/2014WR015549, 2014.

air2stream: air2stream model, available at: https:/github.com/ marcotoffolon/air2stream, last access: 2017.

Akiyama, J. and Heinz, S. G.: Plunging flow into a reservoir: theory, J. Hydraul. Eng., 10, 484-499, 1984.

Ashida, K. and Egashira, S.: Basic study on turbidity currents, P. Jpn. Soc. Civ. Eng., 1975, 37-50, 1975.

Austin, J. A. and Colman, S. M.: Lake Superior summer water temperatures are increasing more rapidly than regional air temperatures: A positive ice-albedo feedback, Geophys. Res. Lett., 34, L06604, https://doi.org/10.1029/2006GL029021, 2007.

Bennett, G. L., Molnar, P., McArdell, B. W., Schlunegger, F., and Burlando, P.: Patterns and controls of sediment production, transfer and yield in the Illgraben, Geomorphology, 188, 68-82, https://doi.org/10.1016/j.geomorph.2012.11.029, 2013.
Birsan, M.-V., Molnar, P., Burlando, P., and Pfaundler, M.: Streamflow trends in Switzerland, J. Hydrol., 314, 312-329, https://doi.org/10.1016/j.jhydrol.2005.06.008, 2005.

Bosshard, T., Kotlarski, S., Ewen, T., and Schär, C.: Spectral representation of the annual cycle in the climate change signal, Hydrol. Earth Syst. Sci., 15, 2777-2788, https://doi.org/10.5194/hess-15-2777-2011, 2011.

Bosshard, T., Carambia, M., Goergen, K., Kotlarski, S., Krahe, P., Zappa, M., and Schär, C.: Quantifying uncertainty sources in an ensemble of hydrological climateimpact projections, Water Resour. Res., 49, 1523-1536, https://doi.org/10.1029/2011WR011533, 2013.

Bouffard, D. and Perga, M.-E.: Are flood-driven turbidity currents hot spots for priming effect in lakes?, Biogeosciences, 13, 35733584, https://doi.org/10.5194/bg-13-3573-2016, 2016.

Caissie, D.: The thermal regime of rivers: a review, Freshw. Biol., 51, 1389-1406, https://doi.org/10.1111/j.13652427.2006.01597.x, 2006.

CH2011: Swiss climate change scenarios CH2011, C2SM, MeteoSwiss, ETH, NCCR Climate, and OcCC, Zurich, Switzerland, 88 pp., ISBN:978-3-033-03065-7, 2011.

Cortés, A., Fleenor, W. E., Wells, M. G., de Vicente, I., and Rueda, F. J.: Pathways of river water to the surface layers of stratified reservoirs, Limnol. Oceanogr., 59, 233-250, https://doi.org/10.4319/lo.2014.59.1.0233, 2014.

Doomen, A. M. C., Wijma, E., Zwolsman, J. J. G., and Middelkoop, H.: Predicting suspended sediment concentrations in the Meuse river using a supply-based rating curve, Hydrol. Process., 22, 1846-1856, https://doi.org/10.1002/hyp.6767, 2008.

Ellison, T. H. and Turner, J. S.: Turbulent entrainment in stratified flows, J. Fluid Mech., 6, 423-448, https://doi.org/10.1017/S0022112059000738, 1959.

Federal Office for the Environment (FOEN): Effects of climate change on water resources and waters, Synthesis report on "Climate Change and Hydrology in Switzerland" (CCHydro) project, Federal Office for the Environment, Bern, Umwelt-Wissen No. 1217, 74 pp., 2012.

Federal Office for the Environment (FOEN): Hydrological data and forecasts, Hydrology Department of the Swiss Federal Office for the Environment (FOEN), available at: www.hydrodaten.admin. ch, last access: December 2017a.

Federal Office for the Environment (FOEN): Climate Change and Hydrology in Switzerland (CCHydro) project model data, Hydrology Department of the Swiss Federal Office for the Environment (FOEN), available at: http://www.bafu.admin.ch/umwelt/ index.html?lang=en, last access: December 2017b.

Fenocchi, A., Rogora, M., Sibilla, S., and Dresti, C.: Relevance of inflows on the thermodynamic structure and on the modeling of a deep subalpine lake (Lake Maggiore, Northern Italy/Southern Switzerland), Limnologica, 63, 42-56, https://doi.org/10.1016/j.limno.2017.01.006, 2017.

Fink, G., Schmid, M., Wahl, B., Wolf, T., and Wüest, A.: Heat flux modifications related to climate-induced warming of large European lakes, Water Resour. Res., 50, 2072-2085, https://doi.org/10.1002/2013WR014448, 2014a.

Fink, G., Schmid, M., and Wüest, A.: Large lakes as sources and sinks of anthropogenic heat: Capacities and limits, Water Resour. Res., 50, 7285-7301, https://doi.org/10.1002/2014WR015509, 2014b. 
Fink, G., Wessels, M., and Wüest, A.: Flood frequency matters: Why climate change degrades deep-water quality of peri-alpine lakes, J. Hydrol., 540, 457-468, https://doi.org/10.1016/j.jhydrol.2016.06.023, 2016.

Foley, B., Jones, I. D., Maberly, S. C., and Rippey, B.: Long-term changes in oxygen depletion in a small temperate lake: Effects of climate change and eutrophication: Oxygen depletion in a small lake, Freshw. Biol., 57, 278-289, https://doi.org/10.1111/j.13652427.2011.02662.x, 2012.

Gaudard, A., Schwefel, R., Vinnå, L. R., Schmid, M., Wüest, A., and Bouffard, D.: Optimizing the parameterization of deep mixing and internal seiches in one-dimensional hydrodynamic models: a case study with Simstrat v1.3, Geosci. Model Dev., 10, 3411-3423, https://doi.org/10.5194/gmd-10-3411-2017, 2017.

GBL/AWA: Canton of Bern lake monitoring data, Office of Water Protection and Waste Management of the Canton of Bern (GBL/AWA), available at: http://www.bve.be.ch/bve/de/ index/wasser/wasser/messdaten/Seen.html, last access: December 2017.

Gillet, C. and Quétin, P.: Effect of temperature changes on the reproductive cycle of roach in Lake Geneva from 1983 to 2001, J. Fish Biol., 69, 518-534, https://doi.org/10.1111/j.10958649.2006.01123.x, 2006.

Glur, L., Wirth, S. B., Büntgen, U., Gilli, A., Haug, G. H., Schär, C., Beer, J., and Anselmetti, F. S.: Frequent floods in the European Alps coincide with cooler periods of the past 2500 years, Sci. Rep.-UK, 3, 2770, https://doi.org/10.1038/srep02770, 2013.

Goudsmit, G.-H., Burchard, H., Peeters, F., and Wüest, A.: Application of $k-\varepsilon$ turbulence models to enclosed basins: The role of internal seiches, J. Geophys. Res., 107, 3230, https://doi.org/10.1029/2001JC000954, 2002.

Hari, R. E., Livingstone, D. M., Siber, R., Burkhardt-Holm, P., and Guettinger, H.: Consequences of climatic change for water temperature and brown trout populations in Alpine rivers and streams, Glob. Change Biol., 12, 10-26, https://doi.org/10.1111/j.1365-2486.2005.01051.x, 2006.

Holgerson, M. A. and Raymond, P. A.: Large contribution to inland water $\mathrm{CO}_{2}$ and $\mathrm{CH}_{4}$ emissions from very small ponds, Nat. Geosci., 9, 222-226, https://doi.org/10.1038/ngeo2654, 2016.

IPCC: Climate Change 2014: Synthesis Report, Contribution of Working Groups I, II and III to the Fifth Assessment Report of the Intergovernmental Panel on Climate Change, edited by: Core Writing Team, Pachauri, R. K., and Meyer, L. A., IPCC, Geneva, Switzerland, 151 pp., 2014.

Isaak, D. J., Wollrab, S., Horan, D., and Chandler, G.: Climate change effects on stream and river temperatures across the northwest U.S. from 1980-2009 and implications for salmonid fishes, Clim. Change, 113, 499-524, https://doi.org/10.1007/s10584011-0326-z, 2012.

Kirillin, G.: Modeling the impact of global warming on water temperature and seasonal mixing regimes in small temperate lakes, Boreal Env. Res, 15, 279-293, 2010.

Kirillin, G., Shatwell, T., and Kasprzak, P.: Consequences of thermal pollution from a nuclear plant on lake temperature and mixing regime, J. Hydrol., 496, 47-56, https://doi.org/10.1016/j.jhydrol.2013.05.023, 2013.

Kobierska, F., Jonas, T., Magnusson, J., Zappa, M., Bavay, M., Bosshard, T., Paul, F., and Bernasconi, S. M.: Climate change effects on snow melt and discharge of a partly glacierized watershed in Central Switzerland (SoilTrec Critical Zone Observatory), Appl. Geochem., 26, 60-62, https://doi.org/10.1016/j.apgeochem.2011.03.029, 2011.

MeteoSwiss: IDAWEB, Federal Office of Meteorology and Climatology (MeteoSwiss), available at: https://gate.meteoswiss.ch/ idaweb/login.do, last access: December 2017.

Mulder, T., Syvitski, J. P. M., and Skene, K. I.: Modeling of erosion and deposition by turbidity currents generated at river mouths, J. Sediment. Res., 68, 124-137, https://doi.org/10.2110/jsr.68.124, 1998.

O'Reilly, C. M., Sharma, S., Gray, D. K., Hampton, S. E., Read, J. S., Rowley, R. J., Schneider, P., Lenters, J. D., McIntyre, P. B., Kraemer, B. M., Weyhenmeyer, G. A., Straile, D., Dong, B., Adrian, R., Allan, M. G., Anneville, O., Arvola, L., Austin, J., Bailey, J. L., Baron, J. S., Brookes, J. D., de Eyto, E., Dokulil, M. T., Hamilton, D. P., Havens, K., Hetherington, A. L., Higgins, S. N., Hook, S., Izmest'eva, L. R., Joehnk, K. D., Kangur, K., Kasprzak, P., Kumagai, M., Kuusisto, E., Leshkevich, G., Livingstone, D. M., MacIntyre, S., May, L., Melack, J. M., MuellerNavarra, D. C., Naumenko, M., Noges, P., Noges, T., North, R. P., Plisnier, P.-D., Rigosi, A., Rimmer, A., Rogora, M., Rudstam, L. G., Rusak, J. A., Salmaso, N., Samal, N. R., Schindler, D. E., Schladow, S. G., Schmid, M., Schmidt, S. R., Silow, E., Soylu, M. E., Teubner, K., Verburg, P., Voutilainen, A., Watkinson, A., Williamson, C. E., and Zhang, G.: Rapid and highly variable warming of lake surface waters around the globe, Geophys Res Lett, 42, 10773-10781, https://doi.org/10.1002/2015GL066235, 2015.

Peeters, F., Livingstone, D. M., Goudsmit, G.-H., Kipfer, R., and Forster, R.: Modeling 50 years of historical temperature profiles in a large central European lake, Limnol. Oceanogr., 47, 186197, https://doi.org/10.4319/lo.2002.47.1.0186, 2002.

Perroud, M. and Goyette, S.: Impact of warmer climate on Lake Geneva water-temperature profiles, Boreal Environ. Res., 15, 255-278, 2010.

Piccolroaz, S., Toffolon, M., and Majone, B.: The role of stratification on lakes' thermal response: The case of Lake Superior, Water Resour. Res., 51, 7878-7894, https://doi.org/10.1002/2014WR016555, 2015.

Råman Vinnå, L., Wüest, A., and Bouffard, D.: Physical effects of thermal pollution in lakes, Water Resour. Res., 53, 3968-3987, https://doi.org/10.1002/2016WR019686, 2017.

Raymond Pralong, M., Turowski, J. M., Rickenmann, D., and Zappa, M.: Climate change impacts on bedload transport in alpine drainage basins with hydropower exploitation, Earth Surf. Proc. Land., 40, 1587-1599, https://doi.org/10.1002/esp.3737, 2015.

Rimmer, A. and Hartmann, A.: Optimal hydrograph separation filter to evaluate transport routines of hydrological models, J. Hydrol., 514, 249-257, https://doi.org/10.1016/j.jhydrol.2014.04.033, 2014.

Sanchez-Lorenzo, A. and Wild, M.: Decadal variations in estimated surface solar radiation over Switzerland since the late 19th century, Atmos. Chem. Phys., 12, 8635-8644, https://doi.org/10.5194/acp-12-8635-2012, 2012.

Schmid, M. and Köster, O.: Excess warming of a Central European lake driven by solar brightening, Water Resour. Res., 52, 81038116, https://doi.org/10.1002/2016WR018651, 2016. 
Schmidt, W.: Über die Temperatur- und Stabilitätsverhältnisse von Seen, Geogr. Ann., 10, 145-177, https://doi.org/10.2307/519789, 1928.

Schwefel, R., Gaudard, A., Wüest, A., and Bouffard, D.: Effects of climate change on deepwater oxygen and winter mixing in a deep lake (Lake Geneva): Comparing observational findings and modeling, Water Resour. Res., 52, 8811-8826, https://doi.org/10.1002/2016WR019194, 2016.

Simstrat: Simstrat source code, available at: https://github.com/ Eawag-AppliedSystemAnalysis/Simstrat, last access: 2017.

Speich, M. J. R., Bernhard, L., Teuling, A. J., and Zappa, M.: Application of bivariate mapping for hydrological classification and analysis of temporal change and scale effects in Switzerland, J. Hydrol., 523, 804-821, https://doi.org/10.1016/j.jhydrol.2015.01.086, 2015.

Swiss Federal Office of Topography (SwissTopo): DHM25 model bathymetry data, available at: https://shop.swisstopo.admin.ch/ en/products/height_models/dhm25, last access: December 2017.

Syvitski, J. P. M. and Lewis, A. G.: The seasonal distribution of suspended particles and their iron and manganese loading in a glacial runoff fiord, Geosci. Can., 19, 13-20, 1992.

Tananaev, N. I.: Hysteresis effect in the seasonal variations in the relationship between water discharge and suspended load in rivers of permafrost zone in Siberia and Far East, Water Resour., 39, 648-656, https://doi.org/10.1134/S0097807812060073, 2012.

Toffolon, M. and Piccolroaz, S.: A hybrid model for river water temperature as a function of air temperature and discharge, Environ. Res. Lett., 10, 114011, https://doi.org/10.1088/17489326/10/11/114011, 2015.

Toffolon, M., Piccolroaz, S., Majone, B., Soja, A.-M., Peeters, F., Schmid, M., and Wüest, A.: Prediction of surface temperature in lakes with different morphology using air temperature, Limnol. Oceanogr., 59, 2185-2202, https://doi.org/10.4319/lo.2014.59.6.2185, 2014.
Van Vliet, M. T. H., Franssen, W. H. P., Yearsley, J. R., Ludwig, F., Haddeland, I., Lettenmaier, D. P., and Kabat, P.: Global river discharge and water temperature under climate change, Glob. Environ. Change, 23, 450-464, https://doi.org/10.1016/j.gloenvcha.2012.11.002, 2013.

Verpoorter, C., Kutser, T., Seekell, D. A., and Tranvik, L. J.: A global inventory of lakes based on high-resolution satellite imagery, Geophys. Res. Lett., 41, 6396-6402, https://doi.org/10.1002/2014GL060641, 2014.

Viviroli, D., Zappa, M., Gurtz, J., and Weingartner, R.: An introduction to the hydrological modelling system PREVAH and its preand post-processing-tools, Environ. Model. Softw., 24, 12091222, https://doi.org/10.1016/j.envsoft.2009.04.001, 2009.

Wahl, B. and Peeters, F.: Effect of climatic changes on stratification and deep-water renewal in Lake Constance assessed by sensitivity studies with a 3D hydrodynamic model, Limnol. Oceanogr., 59, 1035-1052, https://doi.org/10.4319/lo.2014.59.3.1035, 2014.

Wild, M., Ohmura, A., and Makowski, K.: Impact of global dimming and brightening on global warming, Geophys. Res. Lett., 34, L04702, https://doi.org/10.1029/2006GL028031, 2007.

Williamson, C. E., Overholt, E. P., Pilla, R. M., Leach, T. H., Brentrup, J. A., Knoll, L. B., Mette, E. M., and Moeller, R. E.: Ecological consequences of long-term browning in lakes, Sci. Rep.-UK, 5, 18666, https://doi.org/10.1038/srep18666, 2015.

Zhang, G., Yao, T., Xie, H., Qin, J., Ye, Q., Dai, Y., and Guo, R.: Estimating surface temperature changes of lakes in the Tibetan Plateau using MODIS LST data, J. Geophys. Res.-Atmos., 119, 8552-8567, https://doi.org/10.1002/2014JD021615, 2014.

Zhong, Y., Notaro, M., Vavrus, S. J., and Foster, M. J.: Recent accelerated warming of the Laurentian Great Lakes: Physical drivers, Limnol. Oceanogr., 61, 1762-1786, https://doi.org/10.1002/lno.10331, 2016. 